\title{
ASME Code Efforts Supporting HTGRs
}

D. K. Morton

The INL is a

U.S. Department of Energy National Laboratory

operated by

Battelle Energy Alliance

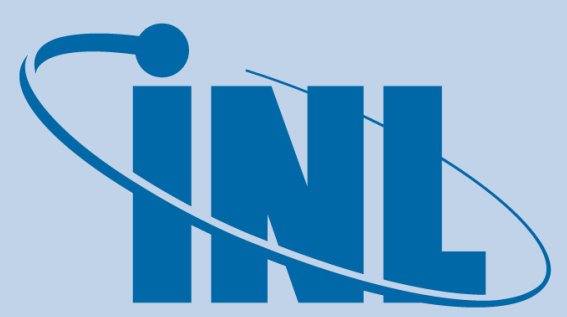

Idaho National Laboratory
September 2010

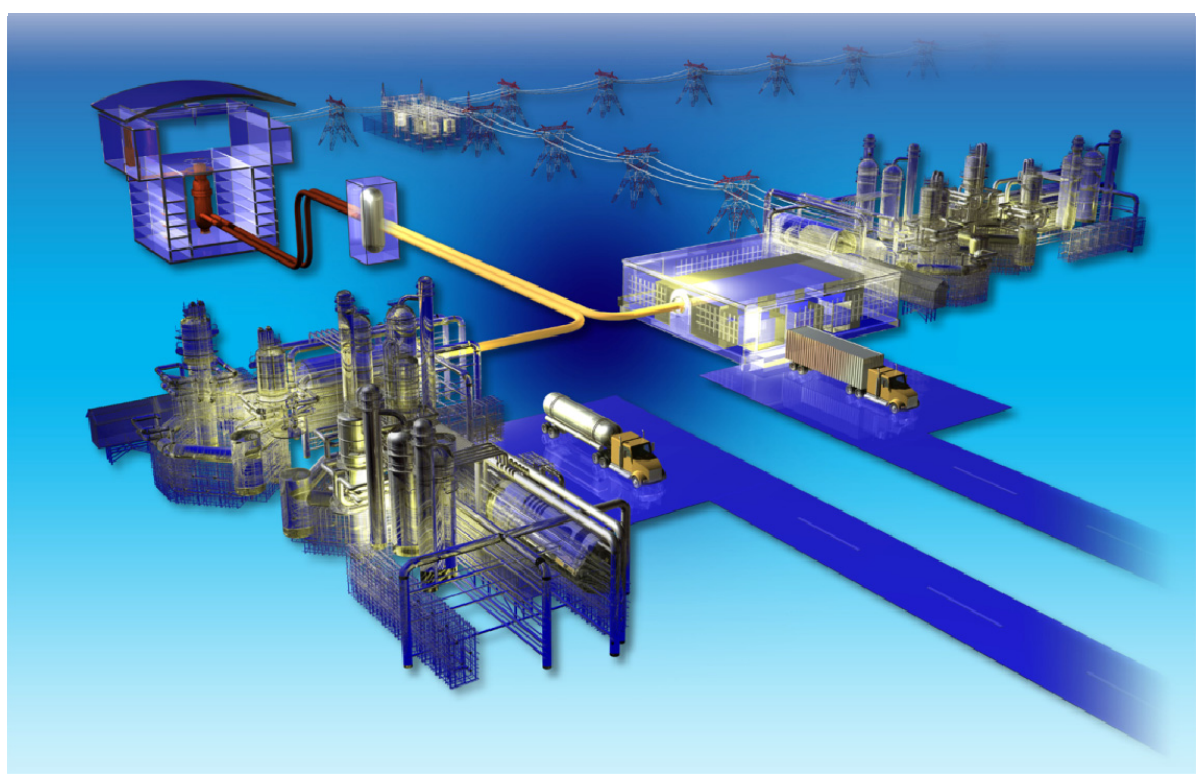




\section{DISCLAIMER}

This information was prepared as an account of work sponsored by an agency of the U.S. Government. Neither the U.S. Government nor any agency thereof, nor any of their employees, makes any warranty, expressed or implied, or assumes any legal liability or responsibility for the accuracy, completeness, or usefulness, of any information, apparatus, product, or process disclosed, or represents that its use would not infringe privately owned rights. References herein to any specific commercial product, process, or service by trade name, trade mark, manufacturer, or otherwise, does not necessarily constitute or imply its endorsement, recommendation, or favoring by the U.S. Government or any agency thereof. The views and opinions of authors expressed herein do not necessarily state or reflect those of the U.S. Government or any agency thereof. 


\section{ASME Code Efforts Supporting HTGRs}

D. K. Morton

September 2010

Idaho National Laboratory

Next Generation Nuclear Plant Project

Idaho Falls, Idaho 83415

Prepared for the

U.S. Department of Energy

Office of Nuclear Energy

Under DOE Idaho Operations Office

Contract DE-AC07-05ID14517 



\title{
Next Generation Nuclear Plant Project
}

\section{ASME Code Efforts Supporting HTGRs}

\author{
INL/EXT-10-19518
}

September 2010

Approved by:

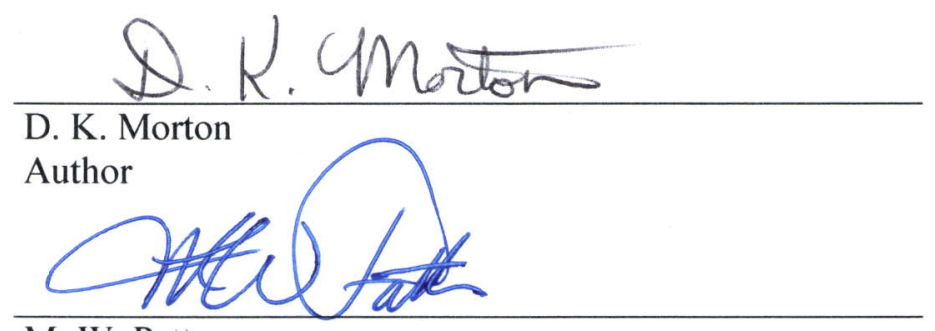

M. W. Patterson

NGNP Engineering Technical Manager
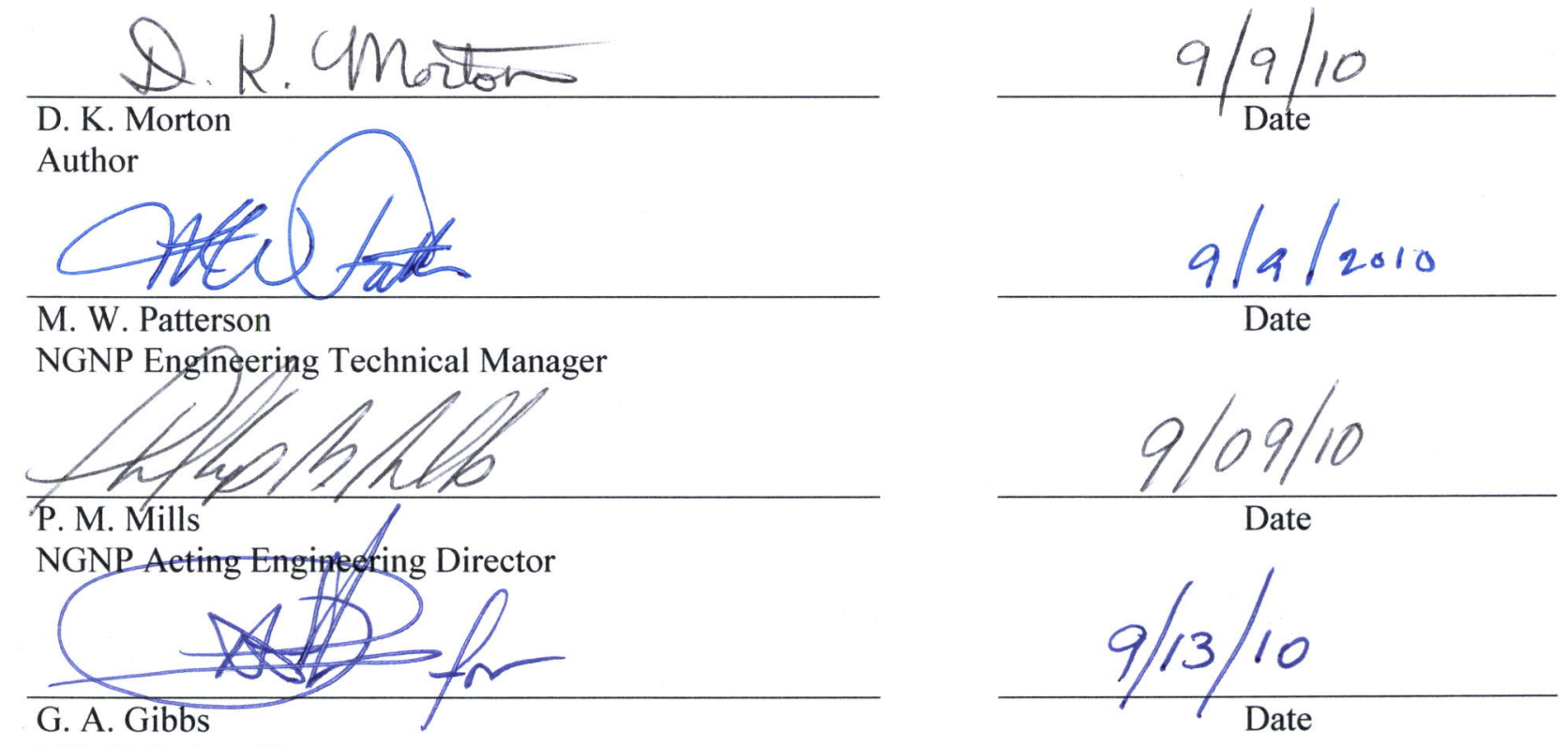

NGNP Project Director 



\begin{abstract}
In 1999, an international collaborative initiative for the development of advanced (Generation IV) nuclear reactors was started. The idea behind this effort was to bring nuclear energy closer to the needs of sustainability, to increase proliferation resistance, and to support concepts able to produce energy (both electricity and process heat) at competitive costs. The U.S. Department of Energy (DOE) has supported this effort by pursuing the development of the Next Generation Nuclear Plant (NGNP), a high temperature gas-cooled reactor. This support has included research and development of pertinent data, initial regulatory discussions, and engineering support of various codes and standards development. This report discusses the various applicable American Society of Mechanical Engineers (ASME) codes and standards that are being developed to support these high temperature gas-cooled reactors during construction and operation. ASME is aggressively pursuing these codes and standards to support an international effort to build the next generation of advanced reactors for a worldwide benefit. It is the support from the international nuclear industry, including DOE and the NGNP Project, that permits ASME to achieve this worthy goal.
\end{abstract}




\section{SUMMARY}

In 1999, an international collaborative initiative for the development of advanced (Generation IV) nuclear reactors was started. The idea behind this effort was to bring nuclear energy closer to the needs of sustainability, to increase proliferation resistance, and to support concepts able to produce energy (both electricity and process heat) at competitive costs. The U.S. Department of Energy (DOE) has supported this effort by pursuing the development of the Next Generation Nuclear Plant (NGNP), a high temperature gas-cooled reactor (HTGR). This support has included research and development of pertinent data, initial regulatory discussions, and engineering support of various codes and standards development.

This report has been written to provide a current update on those major American Society of Mechanical Engineers (ASME) codes and standards (both nuclear and non-nuclear) that will most likely be used in the construction of the NGNP. After a brief history of ASME codes and standards, the purpose of ASME codes and standards are discussed as well as the organizational structure of ASME committees. Next, additional background information on ASME activities occurring in the last few years that have been supporting the development of codes and standards relating to HTGRs is presented. This was done in order to better understand the current Fiscal Year 2010 accomplishments that ASME has achieved regarding codes and standards for HTGRs. Finally, expectations of what ASME activities might achieve in the near future are presented.

This report cites examples that demonstrate ASME is indeed supporting the development of HTGRs by providing numerous codes and standards from which the NGNP can be constructed, licensed, and operated. Not all of the HTGR requirements are currently published, but the codes and standards process is effectively moving forward. The foundation for HTGR codes and standards has already been laid and the development and approval of appropriate codes and standards will continue.

ASME develops and maintains codes and standards that are used internationally to establish rules of safety, develop technology while achieving standardization, and more, all done with a group of volunteers from around the world. DOE and the NGNP Project have also supported this effort. Supporting the Generation IV Reactor Materials Project and supporting NGNP Project personnel and subcontractors to participate in developing ASME codes and standards for HTGRs is beginning to provide substantial benefit. In multiple cases, NGNP Project personnel and subcontractors are assuming committee leadership positions, developing proposals, and actively guiding proposals through the ASME approval process, expediting the issuance of rules for HTGRs. 


\section{ACKNOWLEDGEMENTS}

The author would like to acknowledge the contributions provided by John J. Zudans (Standards Committee on Operation and Maintenance of Nuclear Power Plants), Karl N. Fleming (Standards Committee on Nuclear Risk Management), David C. Stanze (Standards Committee on Qualification of Mechanical Equipment Used in Nuclear Facilities), and Frank J. Schaaf Jr. (BPV Committee on Nuclear Inservice Inspection [XI]) on the latest information regarding activities in their respective committees to support advanced reactors, including high temperature gas-cooled reactors. The author would also like to acknowledge the wealth of information regarding the various ASME codes and standards that is available to the public on ASME's Website at www.asme.org, including the more detailed committee information available to committee members on ASME's C\&S Connect. Finally, the author would like to acknowledge the support provided by Mr. Richard Barnes, Chair of the BPV Committee on Construction of Nuclear Facility Components (III), who recognized the need for the development of high temperature reactor construction rules and foresaw the organizational needs of the associated committees developing those rules. 


\section{CONTENTS}

ABSTRACT vi

SUMMARY viii

ACKNOWLEDGEMENTS $\mathrm{X}$

ACRONYMS xiv

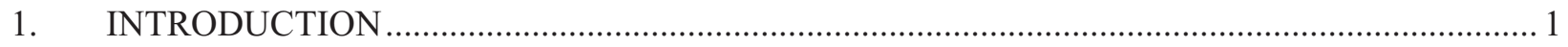

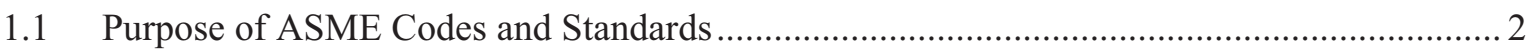

1.1.1 Boiler and Pressure Vessel Code ............................................................................... 2

1.1.2 Probabilistic Risk Assessment Standard ............................................................ 5

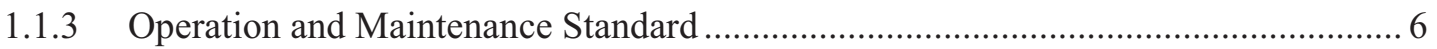

1.1.4 Qualification of Active Mechanical Equipment Used in Nuclear Power

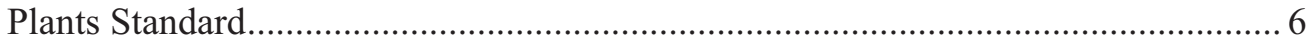

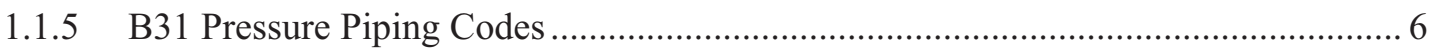

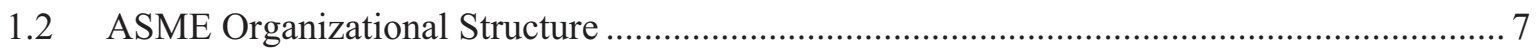

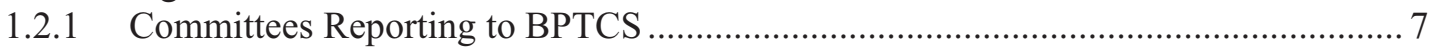

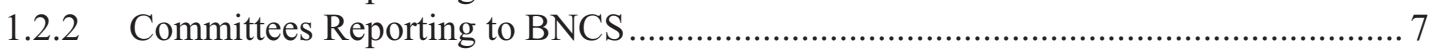

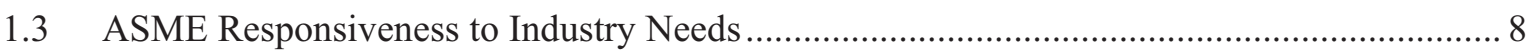

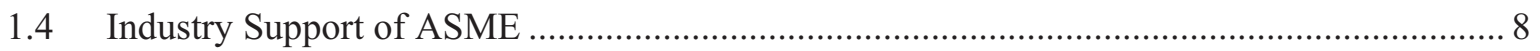

2. REVIEW OF RECENT ASME ACTIVITIES SUPPORTING HTGRs ...................................... 9

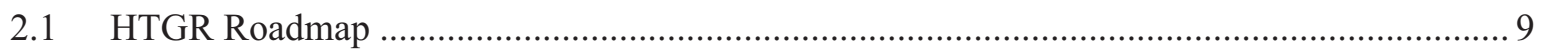

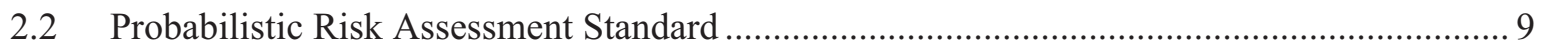

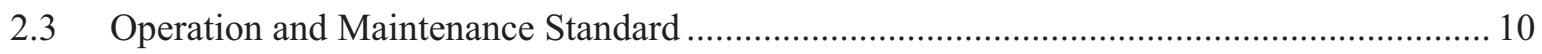

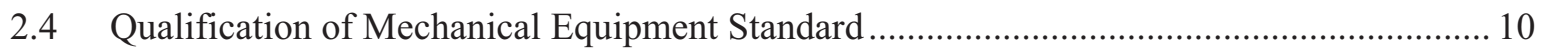

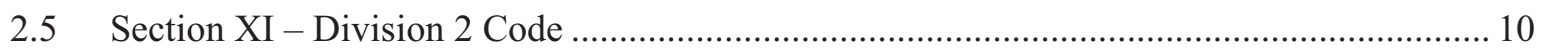

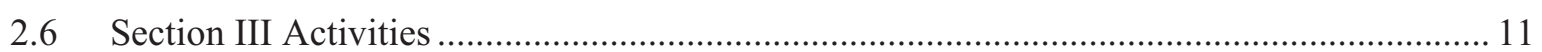

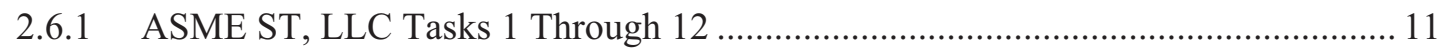

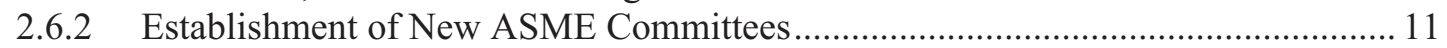

2.6.3 Graphite Core Component Rules ....................................................................... 13

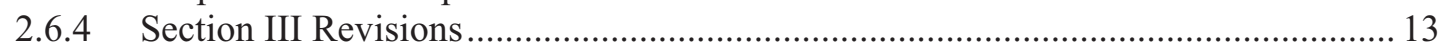

2.7 Section VIII, Supporting B\&PV Sections, and B31 Pressure Piping Codes ....................... 13

3. UPDATE ON ASME ACTIVITIES SUPPORTING HTGRs DURING FY 2010 ....................... 15

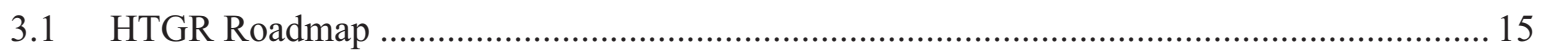

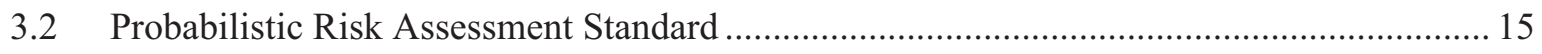

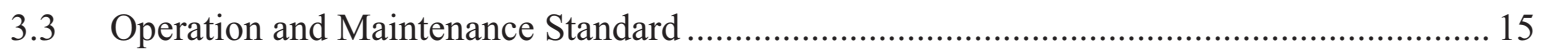

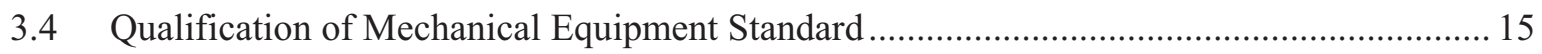

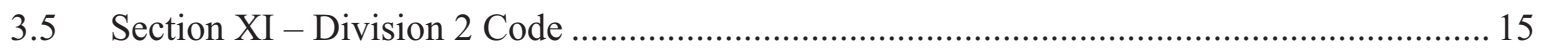

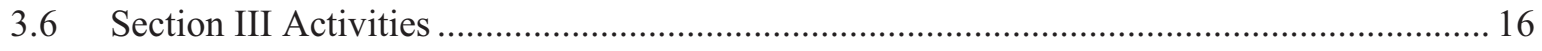

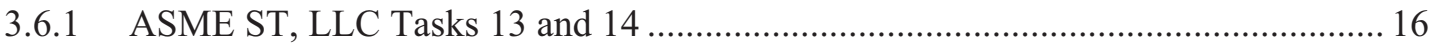

3.6.2 Reorganization of BPV Committee on Construction of Nuclear Facility

Components (III). 


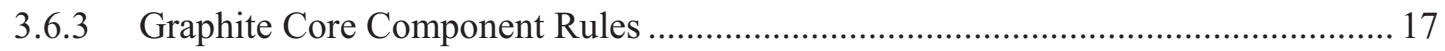

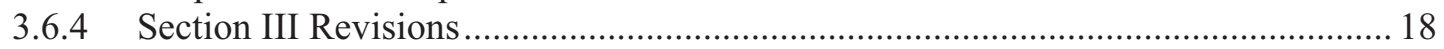

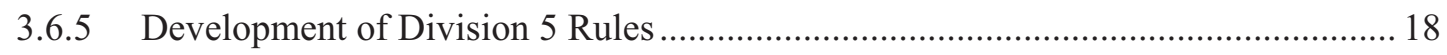

3.7 Section VIII, Supporting B\&PV Sections, and B31 Pressure Piping Codes ....................... 20

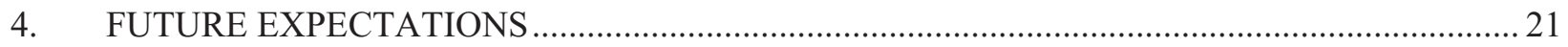

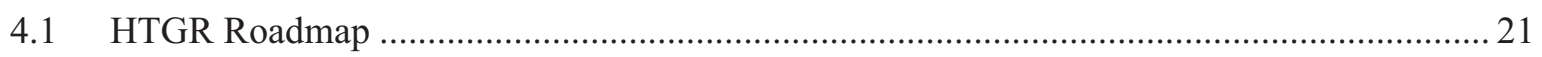

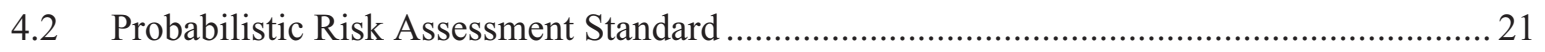

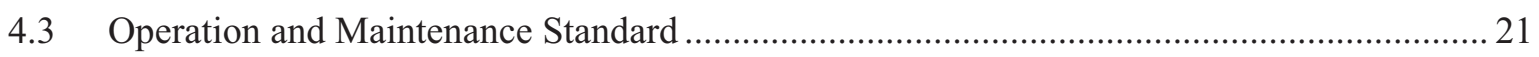

4.4 Qualification of Mechanical Equipment Standard ............................................................... 21

4.5 Section XI - Division 2 Code ....................................................................................... 21

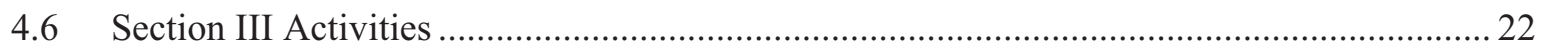

4.7 Section VIII, Supporting B\&PV Sections, and B31 Pressure Piping Codes ....................... 22

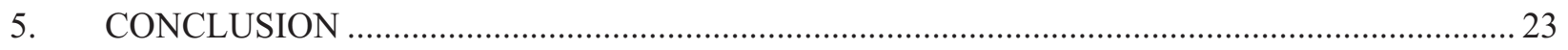

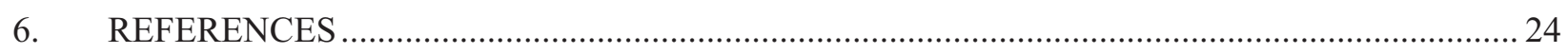

Appendix A BPTCS and BNCS Charters and Associated Committees of Interest .............................. 25

\section{TABLES}

Table 1. Section III - Rules for Construction of Nuclear Facility Components ........................................ 3

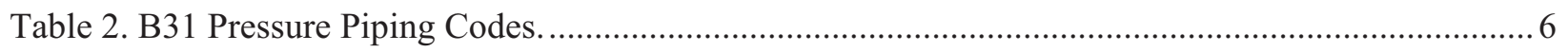

Table 3. Generation IV Reactor Materials Project - Completed Tasks.................................................. 12

Table 4. Division 5 Structure and Origin of Rules Being Incorporated................................................... 19 


\section{ACRONYMS}

$\begin{array}{ll}\text { ANS } & \text { American Nuclear Society } \\ \text { ANSI } & \text { American National Standards Institute } \\ \text { ASME } & \text { American Society of Mechanical Engineers } \\ \text { ASTM } & \text { American Society for Testing and Materials } \\ \text { BNCS } & \text { Board on Nuclear Codes and Standards } \\ \text { BPTCS } & \text { Board on Pressure Technology Codes and Standards } \\ \text { B\&PV } & \text { Boiler and Pressure Vessel } \\ \text { BPV } & \text { see B\&PV } \\ \text { CFR } & \text { U.S. Code of Federal Regulations } \\ \text { DOE } & \text { U.S. Department of Energy } \\ \text { FY } & \text { fiscal year } \\ \text { HTGR } & \text { high temperature gas-cooled reactor } \\ \text { INL } & \text { Idaho National Laboratory } \\ \text { LMR } & \text { liquid metal reactor } \\ \text { LWR } & \text { light water reactor } \\ \text { NDE } & \text { nondestructive examination } \\ \text { NGNP } & \text { Next Generation Nuclear Plant } \\ \text { NRC } & \text { U.S. Nuclear Regulatory Commission } \\ \text { OM } & \text { operation and maintenance } \\ \text { ORNL } & \text { Oak Ridge National Laboratory } \\ \text { PRA } & \text { probabilistic risk assessment } \\ \text { QME } & \text { qualification of mechanical equipment } \\ \text { R\&D } & \text { research and development } \\ \text { RFP } & \text { Request for Proposal } \\ \text { ST } & \text { Standards Technology } \\ \text { WG } & \text { working group } \\ \end{array}$




\section{ASME Code Efforts Supporting HTGRs}

\section{INTRODUCTION}

The American Society of Mechanical Engineers (ASME) has been involved in codes and standards activities for over 125 years. Starting with the Society's first performance test code for steam boilers in 1884, ASME has expanded its areas of responsibility to also include codes and standards for pressure vessels, piping, screw threads, steel stacks, geometric dimensioning and tolerancing, cranes and hoists, elevators and escalators, and much more. The goal of ASME is to be the world leader in mechanical and multidisciplinary engineering codes, standards, conformity assessment programs, and related products and services.

The most widely recognized ASME code is the International Boiler and Pressure Vessel (B\&PV) Code, first originating in 1914. The ASME B\&PV Code is now adopted in part or in its entirety by all 50 states and numerous municipalities and territories of the United States and all the provinces of Canada. It also has additional use beyond North America. The B\&PV Code addresses both nuclear and non-nuclear facilities.

The American National Standards Institute (ANSI) is a privately funded federation of business and industry, standards developers, trade associations, labor unions, professional societies, consumers, academia, and government agencies. ASME is an accredited Standards Developing Organization that meets the due process requirements of ANSI. Codes and standards developed under an accredited program may be designated as American National Standards.

ASME has played a vital role in supporting the nuclear power industry since its inception, when ASME codes, standards and conformity assessment programs originally developed for fossil fuel fired power plants were applied to nuclear power plant construction. Today, ASME nuclear codes and standards exist to ensure public safety, support global trade, develop technology, and foster knowledge transfer while easing government's regulatory burden. By uniting technical and quality requirementsenhanced by a time-proven consensus approach to decision-making-ASME standards can be adopted, applied, and accepted universally.

In 1999, an international collaborative initiative for the development of advanced (Generation IV) reactor power plants was started. The idea behind this effort was to bring nuclear energy closer to the needs of sustainability, to increase proliferation resistance, and to support concepts able to produce energy (both electricity and process heat) at competitive costs. The U.S. Department of Energy (DOE) has supported this effort by pursuing the development of the Next Generation Nuclear Plant (NGNP), a high temperature gas-cooled reactor (HTGR). This support has included research and development (R\&D) of pertinent data, initial regulatory discussions, and engineering support of various codes and standards development.

This report has been written to provide a current update on those major codes and standards (both nuclear and non-nuclear) that will most likely be used in the construction and operation of the NGNP. Some of these codes and standards are adequate as is, some need to be modified, and some need to be newly developed for use with the NGNP. For the purposes of this report (as defined in Section III, Division 1, Subsection NCA-9000 of the ASME B\&PV Code), ${ }^{1}$ the term 'construction' is defined to be "an all-inclusive term comprising materials, design, fabrication, examination, testing, inspection, and certification required in the manufacture and installation of an item." Hence, ASME addresses a broad range of technical issues in their codes and standards. 


\subsection{Purpose of ASME Codes and Standards}

Before proceeding further, it is appropriate to clarify just what a standard and a code actually are. According to $\mathrm{ASME}^{2}$ :
A standard can be defined as a set of technical definitions and guidelines, "how to" instructions for designers, manufacturers and users. Standards promote safety, reliability, productivity and efficiency in almost every industry that relies on engineering components or equipment. Standards can run from a few paragraphs to hundreds of pages, and are written by experts with knowledge and expertise in a particular field who sit on many committees. Standards are considered voluntary because they serve as guidelines, but do not of themselves have the force of law. ASME cannot force any manufacturer, inspector, or installer to follow ASME standards. Their use is voluntary. Standards become mandatory when they have been incorporated into a business contract or incorporated into regulations. A code is a standard that has been adopted by one or more governmental bodies and has the force of law.

The purpose of codes and standards can be summarized in one word: effectiveness. Codes and standards assure that appropriate margins exist for the safe use of the final product. Codes and standards also define the quality levels needed and promote the standardization of components, parts, and items for ease of interchangeability. It is not uncommon for parts (such as a nut and a bolt or piping and a fitting) to be procured in different locations from different companies with the expectation that they will fit together as needed.

The following subsections identify the specific ASME codes and standards that will be addressed in this report in further detail. Each subsection will address the purposes of the code or standard.

\subsubsection{Boiler and Pressure Vessel Code}

As mentioned previously, the ASME B\&PV Code addresses construction rules for both nuclear and non-nuclear facilities. It contains 12 distinct sections. However, for the purposes of this report addressing the major codes and standards that are expected to be used for the NGNP, Sections III, VIII, and XI of the B\&PV Code will be of primary importance along with the critical supporting sections that include Sections II, V, and IX. The 2010 Edition of the ASME B\&PV Code will be used as the basis for defining B\&PV Code content and status.

The B\&PV Code typically addresses components that perform the function of a pressure boundary. This means that the construction rules focus on achieving the pressure integrity of these components for safety purposes. As usual, there are exceptions, especially in Section III, for items like supports and core support structures (although core support structures do experience pressure difference loadings). In these exceptions, the ASME committees felt it was appropriate to develop these additional rules in an effort to provide adequate construction rules for those components whose failure could adversely affect pressure retaining components and to provide a complete set of rules for nuclear power plant construction.

The Foreword to the B\&PV Code contains many additional insights on what the B\&PV Code does and does not address. Issues such as the use of engineering judgment, computer analyses, dimensional tolerances, code cases, dates when Code Editions may be used, and more are discussed. It is strongly suggested that persons interested in gaining a better understanding of the ASME B\&PV Code take the time and read the Foreword. 


\subsubsection{Section III}

Section III of the ASME B\&PV Code addresses the rules for nuclear facilities. Under Division 1, Section III provides requirements for the materials, design, fabrication, examination, testing, inspection, installation, certification, stamping, and overpressure protection of nuclear facility components.

Components include metal vessels and systems, pumps, valves, piping, and core support structures. The components and supports covered by Section III are intended to be installed in a nuclear power system that serves the purpose of producing and controlling the output of thermal energy from nuclear fuel and those associated systems essential to the functions and overall safety of the nuclear power system. It provides requirements for new construction and includes consideration of mechanical and thermal stresses due to cyclic operation. Deterioration, which may occur in service as a result of radiation effects, corrosion, erosion, or instability of the material, is typically not addressed.

Section III also provides requirements for concrete reactor vessels and containments under Division 2 and containment systems for storage and transport packagings for spent nuclear fuel and high-level radioactive waste under Division 3. Division 4 has been assigned for future rules addressing components for fusion reactors and Division 5 has been assigned for future rules associated with high temperature reactors, including HTGRs and liquid metal reactors (LMRs). Table 1 provides a listing of the divisions and subsections that comprise the current Section III. The BPV Committee on Construction of Nuclear Facility Components (III) is responsible for the contents of Section III.

Table 1. Section III - Rules for Construction of Nuclear Facility Components

\begin{tabular}{|c|c|}
\hline $\begin{array}{l}\text { Subsection } \\
\text { Identifier }\end{array}$ & Subsection Title \\
\hline NCA & General Requirements for Division 1 and 2 \\
\hline \multicolumn{2}{|l|}{ Division 1} \\
\hline NB & Class 1 Components \\
\hline NC & Class 2 Components \\
\hline ND & Class 3 Components \\
\hline $\mathrm{NE}$ & Class MC Components \\
\hline NF & Supports \\
\hline NG & Core Support Structures \\
\hline $\mathrm{NH}$ & Class 1 Components in Elevated Temperature Service \\
\hline Appendices & Appendices \\
\hline \multicolumn{2}{|c|}{ Division 2 - Code for Concrete Containments } \\
\hline $\mathrm{CC}$ & Concrete Containments (Prestressed or Reinforced) \\
\hline \multicolumn{2}{|c|}{$\begin{array}{l}\text { Division } 3 \text { - Containments for Transportation and Storage of Spent Nuclear Fuel and High Level Radioactive Materia } \\
\text { and Waste }\end{array}$} \\
\hline WA & General Requirements \\
\hline WB & Class TC Transportation Containments \\
\hline WC & Class SC Storage Containments \\
\hline \multicolumn{2}{|c|}{ Division 4 - (reserved for fusion reactors) } \\
\hline \multicolumn{2}{|c|}{ Division 5 - (reserved for high temperature reactors) } \\
\hline
\end{tabular}




\subsubsection{Section VIII}

Section VIII of the B\&PV Code addresses the rules needed to construct non-nuclear pressure vessels. Pressure boundary vessels not subject to nuclear requirements can utilize these rules. Section VIII provides requirements applicable to the design, fabrication, inspection, testing, and certification of pressure vessels operating at either internal or external pressures exceeding $15 \mathrm{psig}(100 \mathrm{kPa})$. This pressure may be obtained from an external source or by the application of heat from a direct or indirect source, or any combination thereof. Section VIII includes three divisions:

- Division 1 - Basic Coverage

- Division 2 - Alternative Rules

- Division 3 - Alternative Rules for Construction of High Pressure Vessels.

In comparison to the basic design-by-rule approach of Division 1, the requirements of Division 2 on materials, design, and nondestructive examination (NDE) are more rigorous. However, Division 2 also permits higher allowable design stress intensity limits, resulting in more efficient construction (i.e., thinner vessel walls). The rules of Section VIII allow temperatures greater than those allowed in Section III, Division 1 (with the exception of Subsection NH). Division 3 addresses vessels operating at either internal or external pressures generally above 10,000 psi (69 MPa). The BPV Committee on Pressure Vessels (VIII) is responsible for the contents of Section VIII.

\subsubsection{Section $X I$}

Section XI currently contains Division 1 and 3 and provides rules for the examination, inservice testing and inspection, and repair and replacement of components and systems in light water-cooled and liquid metal-cooled nuclear power plants. The Division 2 rules for inspection and testing of components of gas-cooled nuclear power plants were deleted in the 1995 Edition of the ASME B\&PV Code because the need for those requirements ended with the decommissioning of the only gas-cooled reactor (Fort St. Vrain) to which those rules applied.

Application of Section XI of the B\&PV Code begins when the requirements of the construction code (typically Section III) have been satisfied. The rules of Section XI constitute requirements to maintain the nuclear power plant while in operation and to return the plant to service, following plant outages, and repair or replacement activities. The rules require a mandatory program of scheduled examinations, testing, and inspections to evidence adequate safety. The method of NDE to be used and flaw-size characterization are also contained within Section XI. The BPV Committee on Nuclear Inservice Inspection (XI) is responsible for the contents of Section XI.

\subsubsection{Supporting B\&PV Sections}

The major supporting sections of the ASME B\&PV Code that will most likely be used to support the NGNP include the following three sections:

- $\quad$ Section II - Materials

- Part A - Ferrous Material Specifications

- Part B - Nonferrous Material Specifications

- Part C - Specifications for Welding Rods, Electrodes, and Filler Metals

- Part D - Properties.

- Section V - Nondestructive Examination

- Section IX - Welding and Brazing Qualifications. 


\section{Section II}

Part A is a service book to the other B\&PV Code sections, providing material specifications for ferrous materials adequate for safety in the field of pressure equipment. These specifications contain requirements for heat treatment, manufacture, chemical composition, heat and product analyses, mechanical test requirements and mechanical properties, test specimens, and methods of testing. They are designated by SA numbers ${ }^{\mathrm{a}}$ and are derived from American Society for Testing and Materials (ASTM) International 'A' specifications. Part B is also a service book to the other B\&PV Code sections providing material specifications for nonferrous materials adequate for safety in the field of pressure equipment. Containing the same type of information as Part A, the Part B specifications are designated by SB numbers ${ }^{\mathrm{a}}$ and are derived from ASTM International ' $\mathrm{B}$ ' specifications. The Part $\mathrm{C}$ service book provides material specifications for the manufacture, acceptability, chemical composition, mechanical usability, surfacing, testing requirements and procedures, operating characteristics, and intended uses for welding rods, electrodes, and filler metals. These specifications are designated by SFA numbers ${ }^{\mathrm{a}}$ and are derived from American Welding Society specifications. Finally, Part D is a service book to other B\&PV Code sections providing tables of design stress values, tensile and yield strength values, and tables and charts of material properties. Part D facilitates ready identification of specific materials to specific sections of the B\&PV Code. Part D also contains appendices that contain criteria for establishing allowable stress and stress intensity values, the bases for establishing external pressure charts, and information required for the approval of new materials. The BPV Committee on Materials (II) is responsible for the contents of Section II.

\section{Section V}

Section V contains requirements and methods for NDE, which are referenced and required by the other B\&PV Code sections. It also includes manufacturer's examination responsibilities, duties of authorized inspectors, and requirements for inspection, examination, and qualification of personnel. Examination methods are intended to detect surface and internal discontinuities in materials, welds, and fabricated parts and components. A glossary of related terms is also included. The BPV Committee on Nondestructive Examination (V) is responsible for the contents of Section V.

\section{Section IX}

Section IX contains rules relating to the qualification of welding and brazing procedures as required by the other B\&PV Code sections for component manufacture. It also covers rules relating to the qualification and requalification of welders, brazers, and welding and brazing operators in order that they may perform welding or brazing as required by other B\&PV Code sections in the manufacture of components. Welding and brazing data cover essential and nonessential variables specific to the welding or brazing process used. The BPV Committee on Welding and Brazing (IX) is responsible for the contents of Section IX.

\subsubsection{Probabilistic Risk Assessment Standard}

The probabilistic risk assessment (PRA) method plays an important role in ensuring that the operation of a nuclear power plant presents no undue risk to public health and safety. The PRA systematically looks at how the pieces of a complex system work together to ensure safety. The PRA allows analysts to quantify risk and identify what could have the most impact on safety. Hence, the use of the PRA method is important to the proper construction of nuclear power plants and the proper execution of a PRA is best utilized when the methodology follows a proper standard.

a. ASME designations for specifications regarding ferrous materials (SA), nonferrous materials (SB), or for welding rods, electrodes, and filler metals (SFA). 
The Standards Committee on Nuclear Risk Management has issued RA-S-2008, "Standard for Level 1/Large Early Release Frequency Probabilistic Risk Assessment for Nuclear Power Plant Applications."3 This standard sets forth requirements for probabilistic risk assessments used to support risk-informed decisions for commercial light water reactor (LWR) nuclear power plants, and prescribes a method for applying these requirements for specific applications.

\subsubsection{Operation and Maintenance Standard}

The Standards Committee on Operation and Maintenance of Nuclear Power Plants has recently issued OM-2009, "Operation and Maintenance of Nuclear Power Plants.", This standard establishes the requirements for preservice and inservice testing and examination of certain components to assess their operational readiness in LWR power plants. It identifies the components subject to test or examination, responsibilities, methods, intervals, parameters to be measured and evaluated, criteria for evaluating the results, corrective action, personnel qualification, and record keeping. These requirements apply to:

(a) pumps and valves that are required to perform a specific function in shutting down a reactor to the safe shutdown condition, in maintaining the safe shutdown condition, or in mitigating the consequences of an accident; (b) pressure relief devices that protect systems or portions of systems that perform one or more of these three functions; and (c) dynamic restraints (snubbers) used in systems that perform one or more of these three functions.

\subsubsection{Qualification of Active Mechanical Equipment Used in Nuclear Power Plants Standard}

The Standards Committee on Qualification of Mechanical Equipment Used in Nuclear Facilities has issued the qualification of mechanical equipment (QME) document QME-1 - 2007, "Qualification of Active Mechanical Equipment Used in Nuclear Power Plants." 5 This standard describes the requirements and guidelines for qualifying active mechanical equipment (including pumps, valves, and dynamic restraints [snubbers]) used in nuclear power plants. The requirements and guidelines presented include the principles, procedures, and methods of qualification.

\subsubsection{B31 Pressure Piping Codes}

The B31 Code for Pressure Piping Standards Committee is responsible for the series of B31 Codes that address non-nuclear piping system requirements for a variety of industrial applications. Table 2 indicates the B31 identifier and the type of piping addressed by that specific B31 Code.

Table 2. B31 Pressure Piping Codes.

\begin{tabular}{|l|l|}
\hline \multicolumn{1}{|c|}{ Identifier } & \multicolumn{1}{c|}{ Code Title } \\
\hline B31.1 & Power Piping \\
\hline B31.3 & Process Piping \\
\hline B31.4 & Pipeline Transportation Systems for Liquid Hydrocarbons and Other Liquids \\
\hline B31.5 & Refrigeration Piping and Heat Transfer Components \\
\hline B31.8 & Gas Transmission and Distribution Piping Systems \\
\hline B31.9 & Building Services Piping \\
\hline B31.12 & Hydrogen Piping and Pipelines \\
\hline
\end{tabular}

These B31 Codes have similar requirements that have been adapted to the specific industrial application. However, focusing on those major codes and standards that will most likely be utilized by the NGNP, the piping code used for power plants is B31.1. ${ }^{6}$ The B31.1 Code prescribes minimum requirements for the design, materials, fabrication, erection, test, inspection, operation, and maintenance 
of piping systems typically found in electric power generating stations, industrial institutional plants, geothermal heating systems, and central and district heating and cooling systems. The B31.1 Code also covers boiler external piping for power boilers and high temperature, high pressure water boilers in which steam or vapor is generated at a pressure of more than $15 \mathrm{psig}(100 \mathrm{kPa}$ [gage]), and high temperature water is generated at pressures exceeding $160 \mathrm{psig}$ (1103 $\mathrm{kPa}$ [gage]) and/or temperatures exceeding $250^{\circ} \mathrm{F}\left(120^{\circ} \mathrm{C}\right)$. Many B31.1 materials have allowable stress values reflecting temperatures up to $1500^{\circ} \mathrm{F}$ $\left(815^{\circ} \mathrm{C}\right)$.

\subsection{ASME Organizational Structure}

In order to better understand how ASME codes and standards are developed and who develops them, a brief look at the ASME organizational structure is in order.

Supported by ASME staff, the ASME codes and standards are developed and approved by volunteers who follow a specified consensus process proven to be the best path to use for codes and standards development. These volunteers come from a variety of industries, universities, government, and regulatory agencies and have expertise in the various areas to which they are assigned. Volunteers may be on one or more committees. The lower committees (task groups, working groups, or subgroups) work on their respective scope of rules and requirements and, after developing or modifying the requirements and approving them, pass those requirements up to the next higher committee for their respective consideration and approval. The committees identified in Section 1.1 for each of the respective codes or standards discussed were the highest level committee having final determination and responsibility for the content of each code or standard.

ASME's organizational structure focusing on codes and standards begins at the highest level with the Standards and Certification Board of Directors. The Standards and Certification Board of Directors, under the direction of the ASME Board of Governors, will supervise the activities of the society relating to standards and certification. Nine boards report to the Standards and Certification Board of Directors. In terms of focusing on those major codes and standards that will be utilized for NGNP, the Board on Pressure Technology Codes and Standards (BPTCS) and the Board on Nuclear Codes and Standards (BNCS) are clearly the two of most interest and will be discussed in further detail in the following subsections. One can gain a better insight as to which codes and standards each Board is associated with by studying the associated committee listings in Appendix A. The highest level committees report to these Boards.

\subsubsection{Committees Reporting to BPTCS}

As seen in Appendix A for the BPTCS, the most significant committees of interest to NGNP (and hence the associated major codes and standards) include the B31 Code for Pressure Piping Standards Committee, the BPV Committee on Materials (II), the BPV Committee on Welding and Brazing (IX), the BPV Committee of Nondestructive Examination (V), and the BPV Committee on Pressure Vessels (VIII). Hence, the BPTCS has administrative control over the non-nuclear codes and the supporting BP\&V Code sections (also known as the service books).

\subsubsection{Committees Reporting to BNCS}

Again, looking at Appendix A for the BNCS, it is evident that the remaining significant committees of interest to NGNP (and hence the associated major codes and standards) are the nuclear committees, which include the BPV Committee on Construction of Nuclear Facility Components (III), the BPV Committee on Nuclear Inservice Inspection (XI), the Standards Committee on Nuclear Risk Management, the Standards Committee on Operation and Maintenance of Nuclear Power Plants, and the Standards Committee on Qualification of Mechanical Equipment Used in Nuclear Facilities. Further inspection of 
the Appendix A listing for BNCS also shows the Standards Committee on Nuclear Quality Assurance, the Standards Committee on Nuclear Air and Gas Treatment, and the Standards Committee on Cranes for Nuclear Facilities as potential committees of interest. These three committees and their associated standards will obviously be applicable to NGNP but are believed to be viable in their current state and do not need the modification or development efforts that the other codes and standards (e.g., see Section 3.6) need in order to support the NGNP.

\subsection{ASME Responsiveness to Industry Needs}

ASME codes and standards are continually being revised in order to be responsive to industry needs. If the ASME codes and standards were not responsive, they simply would no longer be used. However, the use of ASME codes and standards continues to increase with more users and more applications and the number of effective ASME codes and standards developed continues to increase to support new applications.

For LWRs (including the advanced light water reactors such as the Advanced Passive 1000 reactor design by Westinghouse, Advanced Boiling Water Reactor design by General Electric, Economic Simplified Boiling Water Reactor design by General Electric - Hitachi Nuclear Energy, Evolutionary Power Reactor design by AREVA Nuclear Power, etc.), the ASME B\&PV Code has been updating requirements to reflect not only new design approaches and design methods, but also new materials, new environmental fatigue evaluation methods, and new requirements that reflect the latest licensing approaches instituted by the U.S. Nuclear Regulatory Commission (NRC) specified in Title 10 of the Code of Federal Regulations (CFR), Part 52 (10 CFR Part 52). ${ }^{7}$

For advanced reactors such as LMRs and HTGRs, the publication of new code requirements has not yet begun but results of past efforts will soon be evident as explained in the following section, with an emphasis on efforts to support HTGRs, since that is what is needed for the NGNP.

\subsection{Industry Support of ASME}

The previous Section 1.2 highlights the critical dependency that ASME has on the volunteers that actually generate, revise, maintain, and approve the codes and standards. How do these volunteers gather together to accomplish this feat? It is through the support of the international nuclear and non-nuclear industries (both public and private businesses, universities, government agencies, and regulatory agencies) that provide funding so that these volunteers can attend the ASME meetings and complete their assignments. Included in this knowledgeable support group are DOE, NRC, the national laboratories, and projects such as the NGNP Project at the Idaho National Laboratory. This is truly a unique working relationship. Without the volunteers, industry, and ASME combining together in their efforts, today's codes and standards simply would not exist. 


\section{REVIEW OF RECENT ASME ACTIVITIES SUPPORTING HTGRS}

Before addressing the most recent ASME accomplishments over Fiscal Year (FY) 2010, it is necessary to review recent ASME activities that have occurred over the last few years in order to provide appropriate background information. These accomplishments include planning documents, earlier starts on ASME codes and standards specifically addressing HTGRs or advanced reactors in general, ASME committee reorganization, and ongoing improvements to the construction rules for nuclear and nonnuclear components. Further details are provided in the subsections below.

\subsection{HTGR Roadmap}

During the August 2008 ASME B\&PV Code Week in San Francisco, California, a planning meeting was held to discuss how ASME could most effectively begin to develop ASME Code rules to support the development of HTGRs. It was agreed that a document was needed that could identify the current problems and needs and make recommendations to ASME on how to proceed with this effort. Over the course of the next 12 months with multiple meetings held during ASME B\&PV Code Week and outside of Code Week, a guidance document was developed. Funding was provided by the NRC and logistical support was provided by ASME Standards Technology (ST), LLC. This final document was entitled "Roadmap for the Development of ASME Code Rules for High Temperature Gas Reactors". As discussed in the 'Overview and Executive Summary' of the HTGR Roadmap:

The Roadmap has been developed as a guide to the R\&D and Code development tasks that should be considered in developing rules for High Temperature Gas Cooled Reactors (HTGR). The primary focus of the Roadmap is on the development of a complete set of rules for the design and operating conditions that are being proposed for the Next Generation Nuclear Plant (NGNP) demonstration unit. This is considered to be a Phase I, Part B or intermediate-term activity for the purpose of the Roadmap. However, the Roadmap also mentions a Phase I, Part A activity to modify the existing elevated temperature design rules and to provide a Code Case for graphite and ceramic composite core support structures for interim use for HTGRs. There are some additional tasks that have been identified as a part of the Phase I, Part A effort as noted in the Roadmap. In addition, a Phase II activity is envisioned to develop rules for future generations of HTGRs that are expected to operate at higher temperatures, and for other advanced reactors, such as Liquid Metal (e.g. sodium) Cooled (LMR) designs.

Revision 8 of this document was made available electronically to ASME Committee members on ASME's Website on an interim basis until it could be officially published. It has been used since 2009 to guide the development of construction rules for HTGRs.

\subsection{Probabilistic Risk Assessment Standard}

In response to a 1987 request by the NRC, ASME formed a project team to develop a standard for PRA. Subsequently, the Standards Committee on Nuclear Risk Management was formed. Recognizing that developing a standard that covered all modes and aspects of a PRA was too ambitious to achieve in a single step, the committee focused their initial efforts on a PRA scope that covers internal events (plant hardware failures, internal floods, and human errors), Level 1 (required to estimate core damage frequency), and a limited scope of Level 2 (sufficient to estimate the large early release frequency) for currently operating and licensed LWRs. The American Nuclear Society (ANS) then started to develop PRA standards to cover a wider scope including external events, internal fires, and events initiated during non-full power operating modes. ASME published their first standard in April 2002 and in the following year, ANS published their first standard. 
Two working groups were set up in 2006 to address advanced reactors, one for advanced LWRs and another for advanced non-LWRs. The advanced non-LWR working group decided to develop a new stand-alone standard to address non-LWRs such as HTGRs, LMRs, and any reactor that may have issues of applicability with the existing LWR standards. A draft PRA standard for advanced non-LWRs ${ }^{\mathrm{b}}$ was issued by the Standards Committee on Nuclear Risk Management for public review and comment in October 2008. About 600 comments were received from the U.S. and international PRA community, although many of the comments repeated a much smaller set of issues. The committee is preparing a revised draft that addresses these comments.

Furthermore, ASME and ANS decided to integrate the respective LWR standards into a combined ASME/ANS PRA Standard that was first published in 2009 (a full revision addendum to RA-S-2008) ${ }^{8}$ and this is the current referenced standard approved by ASME and ANS and endorsed by the NRC in Revision 2 of Regulatory Guide 1.200 dated March 2009. ${ }^{9}$

There are a number of parallel codes and standards efforts that will require the application of this advanced non-LWR PRA standard that are of particular interest to the NGNP. One is a draft ANS Standard 53.1, "Nuclear Safety Criteria for the Design of Modular Helium-Cooled Reactor Plants," describing a risk-informed, performance-based approach for designing and licensing modular HTGRs. This draft standard is currently going through the ANS balloting process. The other is the major re-write of ASME Section XI, Division 2 (see Section 2.5), which sets forth requirements for inservice inspection of passive metallic components for modular HTGRs.

\subsection{Operation and Maintenance Standard}

The first five series of Operation and Maintenance (OM) Codes published in the early 1980s were originally written to support older existing nuclear power plants that did not always have a capability to perform certain testing procedures. Therefore, the phrase "if not practical" was included in places just for those older plants that could not comply with the requirement being discussed. In 1987, the first five series were combined into a single OM Code.

More recently, the Standards Committee on Operation and Maintenance of Nuclear Power Plants has been working hard to combine two separate publications (the OM Code and the OM Standards and Guides) into one document. This is being done to ensure that the standards and guides documents were readily available to the users of the OM Code. In addition, a task group began development of a revised OM Code that will provide testing and maintenance requirements for new plants. Since these new plants have not yet been built, the phrase "if not practical" is being deleted.

\subsection{Qualification of Mechanical Equipment Standard}

The first QME-1 standard, "Qualification of Active Mechanical Equipment Used in Nuclear Power Plants," ${ }^{10}$ was published in 1994 and has been regularly updated since then. Most recently, the Committee on Qualification of Mechanical Equipment Used in Nuclear Facilities approved the latest edition of this standard, published in November 2007.

\subsection{Section XI - Division 2 Code}

In 2004, the Special Working Group on High Temperature Gas Reactors began efforts to revitalize

b. ASME/ANS XXXX_draft, "Standard for Probabilistic Risk Assessment for Advanced Non-LWR Nuclear Power Plant Applications", (October 2008 draft standard-not released).

c. ANSI/ANS-53.1-200x, "Nuclear Safety Criteria for the Design of Modular Helium-Cooled Reactor Plants" (May 10, 2010 draft standard-not released). 
Division 2 of Section XI, which addresses inservice inspection requirements for HTGRs. The Special Working Group on High Temperature Gas Reactors has completely rewritten Section XI, Division 2 from that last published in the 1992 Edition (including 1993 Addenda) of Section XI of the B\&PV Code. Although still being revised, this new Division 2 is based on technology of the new HTGRs reflecting passive system performance and addresses metallic components only. It incorporates a risk-informed technology that drives the required periodic examinations. This new methodology is based on the latest draft ASME PRA Standard for advanced non-LWR nuclear power plants. The traditional Inservice Inspection Program has been replaced with the Reliability and Integrity Management Program.

\subsection{Section III Activities}

Many separate and distinct efforts were also accomplished to specifically support the development of HTGR construction rules in Section III. These efforts are discussed in more detail below.

\subsubsection{ASME ST, LLC Tasks 1 Through 12}

In February 2005, ASME met with the DOE to present a proposal for technology development projects addressing research gaps for emerging energy needs. These gaps had been identified from visits and interfaces by ASME delegations with key energy stakeholders in U.S., Canada, Europe, Japan, and South Africa, and included the next generation of commercial nuclear power plants. In support of these advanced (non-LWR) reactors, inclusion of new materials for very high temperatures (graphite, composites and new metallic materials) was discussed.

In June 2005, DOE responded with a draft work scope outlining support of ASME Codes and Standards activities related to the Advance Reactor Program. On June 30, 2005, members of ASME ST, LLC staff met with DOE staff in Washington D.C. to discuss the Generation IV Reactor Materials Project, which included ASME's initial response to the drafted work scope. Several exchanges of comments and responses followed. On August 1, 2005, the final proposal was submitted to DOE-Idaho Operations for their evaluation. DOE and ASME ST, LLC signed a cooperative agreement on September 30, 2005. This agreement provided DOE funding to ASME ST, LLC to develop technical basis documents necessary to update and expand ASME codes and standards for application to advanced reactor systems that operate at elevated temperatures. A steering committee was established to provide overall guidance to the process and the NGNP Project placed two consultants on this committee in December 2007 to assure that the near-term needs of the NGNP were considered.

The fruits of that cooperative agreement have been eleven tasks that have focused on issues pertinent to HTGRs. Many of these tasks addressed NRC concerns with the current evaluation rules in Subsection $\mathrm{NH}$ and ASME Code Cases. As a result of these completed tasks, improvements to ASME Code rules are being implemented. A twelfth task, funded by the NRC but also managed by ASME ST, LLC, focused on NDE development for high temperature service, another issue pertinent to HTGRs. Table 3 lists all twelve completed tasks and the subject matter of those efforts.

\subsubsection{Establishment of New ASME Committees}

Prior to the August 2008 meeting, there were no official ASME B\&PV committees to develop construction rules for HTGRs, excluding the Subgroup on Graphite Core Components discussed below. Only minimal progress on ASME construction rules can be accomplished without a structured committee of experts in place. Hence, Section III leadership began the formation of the necessary working groups and subgroups needed to develop these rules. By the end of FY 2009, two working groups (Working Group on Nuclear High Temperature Gas-Cooled Reactors [WG HTGRs] and the Working Group on Liquid Metal Reactors [WG LMRs]) had been created and populated with volunteers. In addition, a Subgroup on High Temperature Reactors, to whom both WG HTGRs and WG LMRs report, had also 
Table 3. Generation IV Reactor Materials Project - Completed Tasks.

\begin{tabular}{|c|c|c|}
\hline Task & Issues & Results \\
\hline 1 & $\begin{array}{l}\text { - Longer life at higher temperatures than currently } \\
\text { in Subsection NH needed for HTGRs } \\
\text { - Discrepancies in Alloy } 800 \mathrm{H} \text { and Grade } 91 \\
\text { allowable stresses }\end{array}$ & $\begin{array}{l}\text { - } 800 \mathrm{H} \text { data support } 600,000 \mathrm{hr} \text { to } 800^{\circ} \mathrm{C} \text { - more testing } \\
\text { required above } 800^{\circ} \mathrm{C} \text { and above } 750^{\circ} \mathrm{C} \text { for welds } \\
\text { - Grade } 91 \text { data support } 600,000 \mathrm{hr} \text { to } 650^{\circ} \mathrm{C} \text { - base stress } \\
\text { rupture fractures for welds on current worldwide effort }\end{array}$ \\
\hline 2 & $\begin{array}{l}\text { - Identify Subsection NH concerns to be resolved } \\
\text { for licensing }\end{array}$ & $\begin{array}{l}\text { - Creep crack growth in weldments and notches, inelastic } \\
\text { analysis, and environmental effects are primary issues }\end{array}$ \\
\hline 3 & $\begin{array}{l}\text { - Current Subsection } \mathrm{NH} \text { negligible creep and } \\
\text { creep-fatigue damage criteria are overly } \\
\text { restrictive }\end{array}$ & $\begin{array}{l}\text { - Modification to current elastic analysis creep-fatigue rules } \\
\text { formulated and incorporated negligible creep criteria proposal } \\
\text { under consideration }\end{array}$ \\
\hline 4 & $\begin{array}{l}\text { - Update core support structure Code Case N-201 } \\
\text { for HTGRs }\end{array}$ & $\begin{array}{l}\text { - Survey identified materials and operating conditions of interest } \\
\text { - } \mathrm{N}-201 \text { errors corrected and updated to reflect current } \\
\text { provisions of Subsections NG and NH }\end{array}$ \\
\hline 5 & $\begin{array}{l}\text { - Assess creep-fatigue data and damage } \\
\text { evaluation procedures for Grade } 91 \text { and } \\
\text { Hastelloy XR }\end{array}$ & $\begin{array}{l}\text { - Subsection NH procedures overly conservative compared to } \\
\text { data and other international standards } \\
\text { - Potential improvements to Subsection NH reference } \\
\text { methodology identified and evaluated } \\
\text { - Hastelloy XR data support Subsection NH rules }\end{array}$ \\
\hline 6 & $\begin{array}{l}\text { - Minimum creep-rupture stress in Subsection NH } \\
\text { inconsistent with Section II, Part D - impacts wall } \\
\text { sizing and allowable cyclic life }\end{array}$ & $\begin{array}{l}\text { - Inconsistencies have been quantified for Subsection } \mathrm{NH} \\
\text { materials - all but Alloy } 800 \mathrm{H} \text { have problems } \\
\text { - Assembly and assessment of data bases underway }\end{array}$ \\
\hline 7 & $\begin{array}{l}\text { - Intermediate heat exchanger, particularly } \\
\text { compact micro channel concepts with unique } \\
\text { design features, may require new or modified } \\
\text { rules for materials, design, examination, etc. }\end{array}$ & $\begin{array}{l}\text { - Survey completed on current experience base and materials } \\
\text { and operating conditions of interest }\end{array}$ \\
\hline 8 & $\begin{array}{l}\text { - Creep and creep-fatigue crack growth is top } \\
\text { NRC concern } \\
\text { - Subsection NH has design factors and } \\
\text { procedures but not quantitative assessment of } \\
\text { crack initiation and growth }\end{array}$ & $\begin{array}{l}\text { - Available methodologies reviewed and British R5 procedure } \\
\text { selected for development of design rules }\end{array}$ \\
\hline 9 & $\begin{array}{l}\text { - Current Subsection NH rules based on } 1970 \text { s } \\
\text { and 1980s technology - simplified elastic and } \\
\text { inelastic design methods need updating to take } \\
\text { advantage of advances in computing technology } \\
\text { and understanding of material behavior }\end{array}$ & $\begin{array}{l}\text { - } \quad \text { Key elements of "ideal" code developed } \\
\text { - Detailed review and comparison of Subsection NH and other } \\
\text { national and international standards completed }\end{array}$ \\
\hline 10 & $\begin{array}{l}\text { - Creep-fatigue is identified NRC concern and } \\
\text { Tasks } 3 \& 5 \text { identified deficiencies in current } \\
\text { methodologies }\end{array}$ & $\begin{array}{l}\text { - Newly proposed (and/or new to Subsection NH) } \\
\text { methodologies have been selected for detailed review, which } \\
\text { is in progress }\end{array}$ \\
\hline 11 & $\begin{array}{l}\text { - Additional material options in Subsection } \mathrm{NH} \\
\text { advantageous to address unique HTGR } \\
\text { requirements - a preliminary assessment is } \\
\text { needed to focus future effort }\end{array}$ & $\begin{array}{l}\text { - Survey identified } 617,800 \mathrm{H} \text {, Grade } 91 \text {, and } 316 \mathrm{H} \text { of current } \\
\text { interest } \\
\text { - Additional materials to be added for comparison include } 230 \text {, } \\
533 / 508 \text {, Grade } 22 \text { Class 1, Grade } 22 \mathrm{~V}, 316 \mathrm{~L}(\mathrm{~N}) \text { and } 20 \mathrm{Cr} \text { - } \\
\text { 25Ni-Mo-Cb-N }\end{array}$ \\
\hline 12 & $\begin{array}{l}\text { - NDE development needs for unique HTGR } \\
\text { requirements }\end{array}$ & $\begin{array}{l}\text { - Identified potential degradation mechanisms and susceptibility } \\
\text { criteria } \\
\text { - Introduced nondestructive monitoring } \\
\text { - }\end{array}$ \\
\hline
\end{tabular}


been created and populated with volunteers. This creation of an ASME B\&PV Committee infrastructure for advanced non-LWR power plants occurred very rapidly but reflects the desire of the volunteers and their sponsors to move effectively forward to develop construction rules for these reactors.

These committees were assigned the responsibility to develop Division 5 under Section III. The committees were organized so that Division 5, Part 1 addressing HTGRs would be developed by the WG HTGRs. Part 2 of Division 5 would contain rules for liquid metal reactors that would be developed by the WG LMRs.

\subsubsection{Graphite Core Component Rules}

The genesis of the ASME Section III Subgroup on Graphite Core Components (initially referred to as the Graphite Project Team on Core Supports) resulted from a workshop at Oak Ridge National Laboratory (ORNL) on October 15 and 16, 2003. The NRC contracted ORNL to hold the ASME Graphite Code Workshop to seek out all potential stakeholders to gauge their level of interest and recruit members for the code committee. The meeting was attended by representatives from graphite manufactures, gas reactor vendors, and DOE national laboratories to build a consensus on how to restart the previous ASME effort ${ }^{\mathrm{d}}$ of developing a nuclear graphite construction code. The NRC staff also identified a lack of ASTM International material specifications for graphite. As a result of the workshop and discussions between ORNL and ASME, the first meeting of the new graphite committee was held in February 2004. Since that initial meeting, committee members have been actively developing both general requirements and construction rules for graphite core components and the core assembly.

\subsubsection{Section III Revisions}

It must be recognized that committee members are continually involved in efforts to improve the existing Section III rules. These numerous updates and revisions improve the ability of nuclear facilities to comply with the requirements established in the ASME B\&PV Code. Significant examples of recent changes include:

- Making updates to permit the 10 CFR Part 52 licensing process to be used

- Updating the listing of national standards for use

- Approving the use of the 2008 Edition of ASME NQA-1 with the 2009 Addenda.

In terms of more directly supporting HTGRs, efforts were made to update Subsection NH in Division 1 of Section III. Although most of these revisions were more of the editorial nature, such revisions improve the user's comprehension of requirements and eliminate typographical errors.

Revising the ASME B\&PV Code is a continual ongoing process. ASME continues to be responsive to industry needs.

\subsection{Section VIII, Supporting B\&PV Sections, and B31 Pressure Piping Codes}

Much like the Section III revisions, there is ongoing revision and updating of Sections II, V, VIII, and IX and the B31 Pressure Piping Codes. New materials or updates to materials are continually being approved for Section II, improvements to NDE procedures are being made in Section V, enhancements to pressure vessel and piping design methodologies are being addressed in Section VIII and the B31

d. In 1990, the Section III, Division 2, Subsection CE "Design Requirements for Graphite Core Supports," was submitted to the Section III Subcommittee [now the BPV Committee on Construction of Nuclear Facility Components (III)] for review and comment but little progress was made after that initial submittal. 
Pressure Piping Codes, and improved welding procedure requirements are being updated in Section IX for the same reason as Section III is updated. ASME must support the industries for which they develop requirements in order to stay effective and continue their goal of assuring safety. 


\section{UPDATE ON ASME ACTIVITIES SUPPORTING HTGRs DURING FY 2010}

The previous Section 2. established background information on past ASME activities in order to better understand what specific HTGR supporting activities ASME was able to achieve during FY 2010. The following subsections address these major current year achievements.

\subsection{HTGR Roadmap}

Revision 8 of the HTGR Roadmap received further review by the NRC (who funded the development effort) and proposed various minor revisions. These NRC review comments were incorporated into the document and the HTGR Roadmap has been electronically issued on the ASME Website as ASME ST, LLC report STP-NU-045 ${ }^{11}$. BNCS is monitoring the progress Section III has made with regards to construction rules for HTGRs in light of the Roadmap recommendations.

\subsection{Probabilistic Risk Assessment Standard}

Recently, ASME and ANS decided to combine the respective PRA committees that were responsible for developing the PRA standards identified in Section 2.2. The new committee is known as the ASME/ANS Joint Committee on Nuclear Risk Management and its first meeting will be in Boston the week of September 20,2010. The joint committee has a number of subcommittees and working groups to maintain the standard, answer inquiries, make interpretations, and issue addenda and revisions to the standard. The NGNP Project is supporting this Joint Committee in the resolution of comments on the draft PRA standard for advanced non-LWRs.

\subsection{Operation and Maintenance Standard}

The latest OM Code, reflecting the consolidation of the previous OM Code and the OM Standards and Guides was published in February 2010.

The Standards Committee is continuing to develop a revised OM Code that will provide improved testing and maintenance requirements for all new advanced LWR plants. However, due to the generic statement of the technical requirements, the committee believes that this standard can also work very well for all types of new reactors, including HTGRs.

\subsection{Qualification of Mechanical Equipment Standard}

There are no specific ongoing activities for HTGRs being pursued in the Committee on Qualification of Mechanical Equipment Used in Nuclear Facilities. The Committee believes that they have already written their requirements in such a fashion that their rules are applicable to any reactor design.

\subsection{Section XI - Division 2 Code}

The first complete draft of the new Section XI, Division 2 is now complete and approval balloting started at the August 2010 B\&PV Code Week meeting. Regarding additional requirements, current efforts by committee members include the continuing development of a performance based nondestructive qualification appendix to be added to Section XI, Division 2 when the appendix has been approved. 


\subsection{Section III Activities}

Due to the fact that Section III contains design rules needed for preliminary and final design efforts, Section III requirements are leading the way to establish many of the approaches regarding construction rules for HTGRs.

\subsubsection{ASME ST, LLC Tasks 13 and 14}

These two tasks were agreed upon and pursued specifically in order to support the NGNP Project. Per the ASME ST, LLC Request for Proposal (RFP), Task 13 has three parts and reads ${ }^{12}$ :

Part 1:

Develop a data package for consideration by applicable code committees supporting the use of Alloy $800 H$ for extended time and temperature compatible with NGNP design objectives, primarily associated with in-core structures and heat transport systems exposed to hot gas temperatures. The established objective is $850^{\circ} \mathrm{C}$ and $500,000 \mathrm{hr}$. (Note: higher temperatures are desirable as permitted based on available data.)

Part 2:

Develop a data package to support a code case or modification to Code Case N-201 and Subsection NH that supports the use of $800 H$ for infrequent, off-normal temperature excursions compatible with NGNP design objectives. The number of events can tentatively be based on what is specified in Code Case N-499. Allowable stresses should be provided for times and temperatures bounded by times for 100 hours to 10,000 hours and associated temperature limits as high as possible consistent with current data.

Part 3:

Submit draft code rules with data packages developed in Parts 1 and 2 above to the BPV Committee on Materials (II) and the BPV Committee on Construction of Nuclear Facility Components (III) and applicable subgroups for additions to and revisions of material properties information contained in Section II and Section III, Subsection NH. These submittals shall follow the guidance provided in Appendix 4 and 5 of Section II, Part D and are a formal proposed standards action with complete supporting information.

Task 14 is being actively pursued due to the potential of early creep-rupture failures and the desire to address this issue in order to eliminate potential adverse impacts on near term design activities such as the NGNP. Per the ASME ST, LLC RFP, Task 14 also has three parts and directly reads ${ }^{12}$ :

Part 1:

Assess available data on 304 and 316 stainless steel (note: 316 stainless steel is the primary material of interest in this assessment) to determine if there are restrictions that should be placed on specifications and procurement packages or additional acceptance test and examination requirements, e.g., chemical, physical or mechanical properties or processing variables, that would exclude from use those heats of material that are not representative of the data base from which the currently published allowable stress values were derived. (Note: the effectiveness of existing restrictions and requirements shall also be included in the assessment.) 


\section{Part 2:}

In the event that the results of the Part 1 assessment do not identify applicable restrictions and/or additional acceptance requirements, the time and temperature limits beyond which the validity of the current allowable stress values cannot be guaranteed shall be determined. Allowable stresses beyond their range of validity should be recommended for deletion.

Part 3:

Based on the results from Parts 1 and 2 above, prepare a submittal of draft code rules with supporting information. Recommendations should include specific Code words or modification to tables implementing the restrictions that are ready for consideration as a code case or B\&PV Code revision. This submittal shall be a formal proposed standards action and shall have an assigned tracking number.

The funding to pursue these tasks is being provided by DOE. These tasks began in August of 2010 and are scheduled to be completed by September of 2011.

\subsubsection{Reorganization of BPV Committee on Construction of Nuclear Facility Components (III)}

The BPV Committee on Construction of Nuclear Facility Components (III) is currently reorganizing the Section III committee structure and not all of the details are known. Perhaps the biggest driver behind the reorganization was to assure that all proposed rule changes for all of the Divisions 1 through 5 receive a proper and thorough review and approval by committees comprising the three major technical areas:

- Design

- Materials, fabrication, and examination

- General requirements.

In order to assure that this goal is achieved and maintained, it was clarified that all technical committees have representation under at least one of the three technical areas (if not typically more) and that three subcommittees (higher level committees than subgroups) are to be formed that will be responsible for each of these technical areas.

\subsubsection{Graphite Core Component Rules}

At the start of FY 2010, the Subgroup on Graphite Core Components began the process of balloting the graphite rules to the BPV Committee on Construction of Nuclear Facility Components (III). Approval for both the graphite general requirements and the design and construction rules ${ }^{\mathrm{e}}$ for graphite by the BPV Committee on Construction of Nuclear Facility Components (III) and the BNCS was achieved in May 2010. Since that time, the Subgroup continued to improve the graphite rules by submitting additional editorial and technical corrections for approval. NGNP Project personnel have been actively involved in the writing, correction, and approval of these new graphite rules.

e. The Subgroup on Graphite Core Components decided to define 'construction' differently than Division 1 as "All operations required to build the Graphite Core Assembly (manufacture materials, machine Graphite Core Components and install) in accordance with Design Drawings and the Construction Specification." Hence, design and construction are two distinct terms for graphite. 


\subsubsection{Section III Revisions}

The ongoing activities as discussed in Section 2.6.4 continued. In light of the close interaction between Division 1 and Division 5 rules (see Subsection 3.6.5), changes to Division 1 rules were also considered in light of their potential affect on high temperature reactors.

\subsubsection{Development of Division 5 Rules}

The HTGR Roadmap recommended three phases to develop ASME rules for HTGRs.

- Phase I, Part A was to update existing code rules as necessary for immediate application, such as the NGNP.

- Phase I, Part B was to build on that initial effort but develop new rules specifically for HTGRs (to be designed within the next ten years or so) and issue them in a new Division 5 (under Section III) but reflecting current design conditions for the $\mathrm{NGNP}^{\mathrm{f}}$.

- Phase II was to upgrade the new rules in Division 5 to satisfy the needs of stakeholders that would be designing HTGRs designed ten years or more from now with significantly higher component temperatures than those considered in Phase I, Part B.

Efforts to begin defining the structure of Division 5 were officially initiated at the November 2009 ASME B\&PV Code Week. However, there was initial opposition in the lower committees to the proposed Division 5 structure based on not implementing the specific HTGR Roadmap recommendations. However, after initial BPV Committee on Construction of Nuclear Facility Components (III) approval balloting of the graphite general requirements in December 2009, it was recognized that ASME policy requires a Code or Standard to exist in order to issue general requirements. General requirements cannot be issued using a code case approach. Therefore, at the February 2010 B\&PV Code Week meetings, the lower committees agreed that it was appropriate to move forward with a Division 5. This means that the HTGR Roadmap recommendations are still being followed, just that Phase I, Part A and Phase I, Part B are essentially being combined.

This current proposed Division 5 structure is being considered for short-term use only until the ASME committees have sufficient time to develop new construction rules. Table 4 illustrates the Division 5 structure approved by the BPV Committee on Construction of Nuclear Facility Components (III) and the origin of the rules being incorporated. This short-term Division 5 structure is intended to support NGNP needs. Issues such as higher temperature limits and longer hours of operational use (as discussed in Subsection 3.6.1) can be more easily incorporated (via code cases or code revisions) with Division 5 already published.

When the initial draft of Division 5 was developed, the established goal was to develop rules just for HTGRs under Part 1. The WG LMRs agreed with this approach since they wanted additional time to establish their committee goals and plan their respective Part 2 rules. However, at the May 2010 B\&PV Code Week meeting, Section III leadership required the Subgroup on High Temperature Reactors to consider issuing Division 5 with common rules for both HTGRs and LMRs. Another Division 5 draft was generated with common rules.

Balloting of lower ASME committees has already been completed for this latest version of Division 5 with common rules and it was approved. The next step is to ballot for approval the committees representing the three major technical areas of general requirements, design, and materials, fabrication, and examination in the August - September timeframe. Other lower committees reporting to these three

f. Design conditions as defined herein only reflect a reactor outlet temperature of $750-800^{\circ} \mathrm{C}$ and a design life of 60 years.

These provide minimal guidance for the temperature and time extension needed for Alloy $800 \mathrm{H}$ material data. 
Table 4. Division 5 Structure and Origin of Rules Being Incorporated.

\begin{tabular}{|c|c|c|c|c|c|c|}
\hline Class & Subsection & Subpart & $\begin{array}{c}\text { Subsection } \\
\text { ID }\end{array}$ & Title & Code Basis & Scope \\
\hline- & \multirow{4}{*}{$\mathrm{HA}$} & - & - & General Requirements & - & - \\
\hline$A \& B$ & & A & HAA & Metallic Materials & NCA & Metallic \\
\hline A & & B & $\mathrm{HAB}$ & Graphite Materials & Part GA & Graphite \\
\hline A & & C & HAC & Composite Materials & TBD & Composites \\
\hline \multirow{3}{*}{ A } & \multirow{3}{*}{$\mathrm{HB}$} & - & - & Metallic Pressure Boundary Components & - & \multirow{3}{*}{ Metallic } \\
\hline & & A & HBA & Low Temperature Service & NB & \\
\hline & & B & HBB & Elevated Temperature Service & $\begin{array}{c}\text { NH \& } \\
\text { CC N-499 }\end{array}$ & \\
\hline \multirow[b]{3}{*}{ B } & \multirow[b]{3}{*}{$\mathrm{HC}$} & - & - & Metallic Pressure Boundary Components & - & \multirow[b]{3}{*}{ Metallic } \\
\hline & & A & $\mathrm{HCA}$ & Low Temperature Service & $\mathrm{NC}$ & \\
\hline & & B & HCB & Elevated Temperature Service & $\begin{array}{c}\text { CC N-253 } \\
-254,-257 \\
\&-467 \\
\end{array}$ & \\
\hline \multirow{2}{*}{$A \& B$} & \multirow{2}{*}{$\mathrm{HF}$} & - & - & Metallic Supports & - & \multirow{2}{*}{ Metallic } \\
\hline & & A & HFA & Low Temperature Service & NF & \\
\hline \multirow{3}{*}{ A } & \multirow{3}{*}{$H G$} & - & - & Metallic Core Support Structures & - & \multirow{3}{*}{ Metallic } \\
\hline & & A & $\mathrm{HGA}$ & Low Temperature Service & NG & \\
\hline & & B & HGB & Elevated Temperature Service & $\mathrm{CC} \mathrm{N}-201$ & \\
\hline \multirow{3}{*}{ A } & \multirow{3}{*}{$\mathrm{HH}$} & - & - & Non-Metallic Core Support Structures & - & - \\
\hline & & $\mathrm{A}$ & $\mathrm{HHA}$ & Graphite Materials & Part GB & Graphite \\
\hline & & $\mathrm{B}$ & $\mathrm{HHB}$ & Composites Materials & TBD & Composites \\
\hline$A \& B$ & Appendices & None & Appendices & Mandatory and Nonmandatory Appendices & TBD & All \\
\hline \multicolumn{7}{|c|}{ TBD - To be developed } \\
\hline \multicolumn{7}{|c|}{$\begin{array}{l}\text { were chosen for high temperature reactors, reflecting: } \\
\text { nt classification categories, respectively, for structures, } \\
\text { will use non-nuclear standards such as B\&PV Code Se } \\
\text { icable (as shown above) or subsection specific and atte }\end{array}$} \\
\hline
\end{tabular}

technical area committees and the remaining mid-level committees reporting to the BPV III Committee on Construction of Nuclear Facility Components (III) are simultaneously being balloted for comment. Eventual plans are to submit Division 5 to the BPV Committee on Construction of Nuclear Facility Components (III) by the November 2010 B\&PV Code Week meeting. This aggressive schedule is being pursued so that Division 5 can be published with the 2011 Addenda in July 2011. If Division 5 is not approved in time for the 2011 Addenda, there is the potential for a special issuance of Division 5 rather than having to wait for the next scheduled publication of the ASME B\&PV Code in July of 2013. The development of Division 5 has been assigned to a NGNP Project individual who is responsible for generating and updating the draft proposal and guiding it through the ASME approval process. 


\subsection{Section VIII, Supporting B\&PV Sections, and B31 Pressure Piping Codes}

The ongoing activities as discussed in Section 2.7 continued. Without further details on the normal and off-normal operating conditions of the NGNP and whether these loadings fit within the limits currently established by these codes still needs to be evaluated when NGNP design information becomes available.

Preliminary efforts to have the diffusion bonding process be incorporated into the ASME B\&PV Code have already begun. Idaho National Laboratory, with NGNP Project funding support, is gathering data on the diffusion bonding process using Alloy $800 \mathrm{H}$ material. The eventual goal is to have Section III rules in place for equipment (such as an intermediate heat exchanger) using the diffusion bonding process. But the first step is for the BPV Committee on Welding and Brazing (IX) to recognize this advanced joining process. Rules permitting diffusion bonding are moving forward in Section IX. 


\section{FUTURE EXPECTATIONS}

It is always difficult to accurately predict the future, especially regarding the ASME B\&PV Committees since the members are volunteers and have multiple demands on their time. However, the following subsections briefly discuss what the expectations are for ASME codes and standards that address HTGRs.

\subsection{HTGR Roadmap}

The HTGR Roadmap will continue to be used as guidance for future ASME codes and standards development relating to HTGRs. Since the HTGR Roadmap is a collection of recommendations and not mandates, alternative activities reflecting current needs can always be pursued but the overall philosophy behind the HTGR Roadmap is still considered viable.

\subsection{Probabilistic Risk Assessment Standard}

The joint ASME/ANS committee expects to begin balloting of the revised draft PRA standard for advanced non-LWRs in early 2011.

\subsection{Operation and Maintenance Standard}

The Standards Committee on Operation and Maintenance of Nuclear Power Plants expects to complete the latest draft proposal of the improved OM Code in late 2010 and hopes to start balloting in December 2010. As previously mentioned, due to the generic statement of the technical requirements, the Committee believes that this standard can also work very well for all types of reactors, including HTGRs. This Standards Committee could benefit from additional NGNP design information in terms of more detailed information of the types of equipment and operating conditions. Reviewing the contents of a published Division 5 might also provide additional insights to this committee and allow for better planning.

\subsection{Qualification of Mechanical Equipment Standard}

There are no specific ongoing HTGR activities being pursued in the Committee on Qualification of Mechanical Equipment Used in Nuclear Facilities. The Committee believes that they have already written their requirements in such a fashion that their rules are applicable to any reactor design. Committee leadership is also aware that they may need additional personnel with the appropriate backgrounds in the advanced plant concepts in order to prepare unique qualification requirements for advanced reactors such as HTGRs and LMRs, if additional requirements become necessary.

\subsection{Section XI - Division 2 Code}

The goal of the BPV Committee on Nuclear Inservice Inspection (XI) is the inclusion of the new Division 2 into the 2013 Edition of the ASME B\&PV Code. This estimate is based on the latest ASME B\&PV publication schedule which will eliminate addenda but publish on a two-year interval starting with the last addenda issuance in 2011. It would also benefit the BPV Committee on Nuclear Inservice Inspection (XI) to review the contents of a published Division 5 for additional insights and proper integration of requirements. This committee is also moving forward with plans to address rules for graphite and composite materials once additional prismatic and pebble bed design details become available. 


\subsection{Section III Activities}

In terms of supporting HTGRs, the most significant Section III activity is the approval and publication of Division 5. Expectations are that the publication of Division 5 will occur either in mid2011 or mid-2012. Of course, this is dependent on gaining acceptance of the proposed Division 5 by all of the ASME committees. Having an existing Division 5 in place makes code revisions easier to achieve since either code cases or code revisions can be pursued. For example, getting the extension of temperature limits and the hours of operational use for Alloy $800 \mathrm{H}$ published can be achieved either way, depending on publication timing and when the rules are needed.

The results from Tasks 13 and 14 are expected to be completed in late 2011 so the expected incorporation of those results into Division 5 rules could be sometime in mid to late 2012. Due to the time it takes the various committees to digest the various data and analytical evaluation proposals from the other Generation IV Reactor Materials Project tasks, it is expected that Subsection NH revision proposals will also begin to emerge from the lower committees in 2011 and continue for a number of years due to the wealth of recommendations made. Benefitting from the joint efforts of Idaho National Laboratory and Oak Ridge National Laboratory regarding the elevated temperature testing of Alloy $800 \mathrm{H}$ and Alloy 617, ASME committees should have a substantial database within the next few years from which Alloy 617 can actually be brought into Section III, Subsection NH and the material data associated with Alloy $800 \mathrm{H}$ can be further enhanced.

Expectations are that enhancements to the graphite rules would continue as needed simultaneously with the Subgroup on Graphite Core Components beginning to turn its focus onto ASME B\&PV Code rules for composite materials to be used for core support structures or reactor internals. Any pertinent insights gained from the ongoing graphite testing at Idaho National Laboratory and Oak Ridge National Laboratory are expected to be brought forth to the Subgroup for their consideration.

With incorporation of diffusion bonding requirements into Section IX, efforts will continue to develop a complete set of Section III rules for components using the diffusion bonding process, such as intermediate heat exchanges. The most significant areas to be addressed will be the many design, fabrication, and examination issues.

Initial efforts have begun at Idaho National Laboratory to gather information regarding the structural performance of dissimilar welds at elevated temperatures. Once this initial data gathering effort is complete, if appropriate, efforts could begin to request ASME to evaluate the information for possible consideration in the revision of its existing rules regarding weld design, weld fabrication, or weld examination, especially for elevated temperature service.

\subsection{Section VIII, Supporting B\&PV Sections, and B31 Pressure Piping Codes}

Without further NGNP design details indicating otherwise, the current Section VIII, supporting B\&PV Sections, and B31 Pressure Piping Codes are expected to be adequate as is for construction of the NGNP. Of course, new materials, higher temperature limits, or clarification of advanced NDE needs for certain NGNP components may be necessary. However, those issues will be addressed when further details become known.

The incorporation of diffusion bonding requirements (supporting compact heat exchanger design that could be used for the intermediate heat exchanger) into Section IX is expected by 2013 and possibly in time for the 2011 Addenda. 


\section{CONCLUSION}

ASME has a formidable task. ASME develops and maintains codes and standards that are used internationally to establish rules of safety, develop technology while achieving standardization, and more. This is all done with a group of volunteers from around the world, many of whom have strong opinions on the proper approach to issues. Yet, the ASME consensus process has worked in the past and continues to work effectively.

DOE and the NGNP Project have also supported this effort. Supporting the Generation IV Reactor Materials Project and supporting NGNP Project personnel and subcontractors to participate in developing ASME codes and standards for HTGRs is beginning to provide substantial benefit. In multiple cases, NGNP Project personnel and subcontractors are assuming committee leadership positions, developing proposals, and actively guiding proposals through the ASME approval process, expediting the issuance of rules for HTGRs. But more work is needed to complete this significant and valuable effort. As evidenced in this report, continued funding support will yield multiple major contributions toward the development of HTGRs.

This report details how ASME is supporting the development of HTGRs by discussing numerous codes and standards from which the NGNP can be constructed, licensed, and operated. Not all of the HTGR requirements are currently published, but the codes and standards process is effectively moving forward. The foundation for HTGR codes and standards has already been laid and the development and approval of construction rules will continue. ASME is aggressively pursuing the issuance of these codes and standards to support an international effort to build the next generation of advanced reactor power plants for a worldwide benefit. 


\section{REFERENCES}

1. American Society of Mechanical Engineers, 2010, “ASME Boiler and Pressure Vessel Code," July 1, 2010 .

2. American Society of Mechanical Engineers, "About Codes and Standards," www.asme.org/Codes/About/FAQs/Codes_Standards.cfm, accessed August 12, 2010.

3. ASME RA-S-2008, "Standard for Level 1 / Large Early Release Frequency Probabilistic Risk Assessment for Nuclear Power Plant Applications," American Society of Mechanical Engineers, 2008.

4. ASME OM-2009, "Operation and Maintenance of Nuclear Power Plants," American Society of Mechanical Engineers, February 26, 2010.

5. ASME QME-1-2007, "Qualification of Active Mechanical Equipment Used in Nuclear Power Plants," American Society of Mechanical Engineers, November 28, 2007.

6. ASME B31.1-2007, "Power Piping," American Society of Mechanical Engineers, December 7, 2007.

7. 10 CFR Part 52, "Early Site Permits; Standard Design Certifications; and Combined Licenses for Nuclear Power Plants," Code of Federal Regulations, U.S. Nuclear Regulatory Commission, January $1,2010$.

8. ASME/ANS RA-Sa-2009, "Standard for Level 1/ Large Early Release Frequency Probabilistic Risk Assessment for Nuclear Power Plant Applications," Addendum to RA-S-2008, American Society of Mechanical Engineers, American Nuclear Society, February 2009.

9. U.S. Nuclear Regulatory Commission, "An Approach for Determining the Technical Adequacy of Probabilistic Risk Assessment Results for Risk-Informed Activities," Regulatory Guide 1.200, Revision 2, March 2009.

10. ASME QME-1-1994, "Qualification of Active Mechanical Equipment Used in Nuclear Power Plants," American Society of Mechanical Engineers, June 30, 1994.

11. ASME Standards Technology, LLC, 2010, "Roadmap to Develop ASME Code Rules for the Construction of High Temperature Gas Cooled Reactors (HTGRs)," STP-NU-045, September 2010, electronically issued at: http://stllc.asme.org/News_Announcements.cfm.

12. ASME Standards Technology, LLC, 2010, "RFP-ASMEST-11-04," Request for Proposals, http://files.asme.org/STLLC/23256.pdf, accessed August 12, 2010. 


\section{Appendix A}

\section{BPTCS and BNCS Charters and Associated Committees of Interest}




\section{Board on Pressure Technology Codes and Standards}

Charter:

Management of all ASME activities related to codes, standards, guidelines, and accreditation programs directly applicable to non-nuclear pressure containing equipment.

\section{Associated Committees}

ASME/API Joint Committee on Fitness for Service

B16 Standardization of Valves, Flanges, Fittings, and Gaskets Standards Committee

B16 Materials Technical Committee

ISO/TC 153 - Valves (B16)

ISO/TC 153/SC 1 - Design, Manufacturing, Marking and Testing (B16)

ISO/TC 153/SC 2 - Valve Actuator Attachment (B16)

ISO/TC 5 Ferrous Metal Pipes and Metallic Fittings (B16)

ISO/TC 5/SC 10 - Metallic Flanges and Their Joints (B16)

ISO/TC 5/SC 5 - Threaded Fittings, Solder Fittings, Welded Fittings, Pipe Threads, Thread Gauge (B16)

Subcommittee B - Threaded Fittings (Except Steel), Flanges, and Flanged Fittings (B16)

Subcommittee C - Steel Flanges and Flanged Fittings (B16)

Subcommittee F - Steel Threaded and Welding Fittings (B16)

Subcommittee G - Gaskets for Flanged Joints (B16)

Subcommittee J - Copper and Copper Alloy Flanges, Flanged Fittings, and Solder Joint Fittings (B16)

Subcommittee L - Gas Shutoffs and Valves (B16)

Subcommittee N - Steel Valves and Face-to-Face and End-to-End Dimensions of Valves (B16)

BPV Committee on Materials (II)

Honorary Members of BPV Committee on Materials (II)

Special Working Group On Non-Metallic Materials (SC II)

Subgroup on External Pressure (SC II \& SC-D)

Subgroup on Ferrous Specifications (SC II)

Subgroup on International Material Specifications (SC II)

Subgroup on Nonferrous Alloys (SC II)

Subgroup on Physical Properties (SC II)

Subgroup on Strength of Weldments (SC II \& SC IX)

Subgroup on Strength, Ferrous Alloys (SC II)

BPV Committee on Nondestructive Examination (V)

Subgroup on General Requirements/Personnel Qualifications and Inquiries (SC V)

Subgroup on Surface Examination Methods (SC V)

Subgroup on Volumetric Methods (SC V)

Working Group on Acoustic Emissions (SG-VM) (SC V)

Working Group on Radiography (SG-VM) (SC V)

Working Group on Ultrasonics (SG-VM) (SC V)

BPV Committee on Power Boilers (I)

BPV Committee on Transport Tanks (XII)

BPV Committee on Welding and Brazing (IX)

Subgroup on Brazing (SC IX)

Subgroup on General Requirements (SC IX)

Subgroup on Materials (SC IX)

Subgroup on Performance Qualification (SC IX)

Subgroup on Procedure Qualification (SC IX) 


\section{B31 Code for Pressure Piping Standards Committee}

B31 Conference Group

B31 Executive Committee

B31 Fabrication and Examination Committee

B31 Forever Medal Nominating Committee

B31 Honors \& Awards Committee

B31 Materials Technical Committee

B31 Mechanical Design Technical Committee

B31 Qualification of Pipeline Personnel Technical Committee

B31 Qualification of Pipeline Personnel Technical Committee, India IWG

B31.1 Power Piping Section Committee

B31.1 Inquiry Review Task Group

B31.1 International Working Group - India

B31.1 Subgroup on Design

B31.1 Subgroup on Fabrication and Examination

B31.1 Subgroup on Materials

B31.1 Subgroup on Operation and Maintenance

B31.1 Subgroup on Special Assignments

B31.1 Subgroup on General Requirements

B31.12 Hydrogen Piping and Pipelines Section Committee

B31.3 Process Piping Section Committee

B31.3 International Review Group

B31.3 Process Piping, India IWG

B31.3 Subgroup on Design (SG-B)

B31.3 Subgroup on Edit (SG-C)

B31.3 Subgroup on Fabrication, Examination and Testing (SG-E)

B31.3 Subgroup on General Requirements (SG-A)

B31.3 Subgroup on High Pressure Piping (SG-G)

B31.3 Subgroup on High Purity Piping (SG-H)

B31.3 Subgroup on Inquiry Review (SG-IR)

B31.3 Subgroup on Materials (SG-D)

B31.3 Subgroup on Non-Metallic Piping (SG-F)

B31.3 Subgroup on Procedures (SG-O)

B31.4/11 Liquid and Slurry Piping Transportation Systems

B31.4 Liquid and Slurry Transportation Systems, India IWG

B31.4/B31.8 Joint Executive Committee

B31.5 Refrigeration Piping Section Committee

B31.8 Executive Committee

B31.8 Gas Transmission and Distribution Piping Systems Section Committee

B31.8 Gas Transmission and Distribution Piping Systems, India IWG

B31.8 Subgroup on Design, Materials and Construction

B31.8 Subgroup on Editorial Review

B31.8 Subgroup on Offshore Pipelines

B31.8 Subgroup on Operation and Maintenance

B31.9 Building Services Piping Section Committee

Bioprocessing Equipment Standards Committee (BPE)

BPV Committee on Fiber-Reinforced Plastic Pressure Vessels (X)

BPV Committee on Heating Boilers (IV)

Committee on Turbine Water Damage Prevention (TWDP) 


\section{Pressure Technology Post Construction Committee}

BPV Committee on Pressure Vessels (VIII)

Special Working Group on Bolted Flanged Joints (BPV VIII)

Special Working Group on Graphite Pressure Equipment (SC VIII)

Subgroup on Design (SC VIII)

Subgroup on Fabrication and Inspection (SC VIII)

Subgroup on General Requirements (SC VIII)

Subgroup on Heat Transfer Equipment (SC VIII)

Subgroup on High Pressure Vessels (SC VIII)

Task Group on Design (SC VIII Div. 3)

Task Group on Impulsively Loaded Vessels (SC VIII)

Task Group on Materials (SC VIII Div. 3)

Subgroup on Materials (SC VIII)

Subgroup on Toughness (SC II \& SC VIII)

Pressure Vessels for Human Occupancy (PVHO)

Reinforced Thermoset Plastic Corrosion Resistant Equipment Main Committee (RTP)

Structures for Bulk Solids (SBS)

Technical Oversight Management Committee (TOMC)

Notes:

1. Lower reporting committees are not shown for those highest level committees that are not of significant interest to the development of rules for HTGRs.

2. BPTCS organization structure as of August 25, 2010. 


\section{Board on Nuclear Codes and Standards}

Charter:

To manage all ASME activities related to codes, standards, and accreditation programs directly applicable to nuclear facilities and technology. To manage the development of codes, standards, and accreditation programs developed by committees under its jurisdiction, the board is providing procedural due process.

\section{Associated Committees}

\section{BNCS - Honorary Members}

\section{BNCS Committee on Honors and Awards}

\section{BNCS Task Group on New Reactors and Globalization}

BNCS Task Group on Regulatory Endorsement

BPV Committee on Construction of Nuclear Facility Components (III)

Joint ACI-ASME Committee on Concrete Components for Nuclear Service (SC-3C)

Working Group on Design (SC-3C)

Working Group on Materials, Fabrication and Examination (SC-3C)

Working Group on Modernization (SC-3C)

Special Working Group on Editing and Review (SC III)

Special Working Group on Polyethylene Pipe (SC III)

Subcommittee on Nuclear Power Honorary Members (SC III)

Subgroup on Containment Systems for Spent Fuel and High Level Waste Transport Packagings (SC III)

Subgroup on Design (SC III)

Special Working Group on Environmental Effects (SG-D) (SC III)

Working Group on Core Support Structures (SG-D) (SC III)

Working Group on Design Methodology (SG-D) (SC III)

Working Group on Design of Division 3 Containments (SG-D) (SC III)

Working Group on Piping (SG-D) (SC III)

Working Group on Probabilistic Methods in Design (SG-D) (SC III)

Working Group on Pumps (SG-D) (SC III)

Working Group on Supports (SG-D) (SC III)

Working Group on Valves (SG-D) (SC III)

Working Group on Vessels (SG-D) (SC III)

Subgroup on Design Analysis (BPV III)

Subgroup on Elevated Temperature Design (BPV III)

Subgroup on Fatigue Strength (BPV III)

Subgroup on General Requirements (SC III \& 3C)

Working Group - Duties and Responsibilities (SG-GR) (BPV III)

Working Group on Quality Assurance, Certification and Stamping (SG-GR) (BPV III)

Subgroup on Graphite Core Components (SC III)

Subgroup on Industry Experience for New Plants (BPV III \& BPV XI)

Subgroup on Materials, Fabrication, and Examination (SC III)

Subgroup on Pressure Relief (SC III)

Subgroup on Strategy and Management (SC III, Divisions 1 and 2)

Special Working Group for New Advanced Light Water Reactor Plant Construction Issues

Subgroup on High Temperature Reactors (BPV III)

Subgroup on Magnetic Confinement Fusion Energy Devices (BPV III)

Subgroup on Management Resources

Working Group on Liquid Metal Reactors (BPV III)

Working Group on Nuclear High Temperature Gas-Cooled Reactors (BPV III) 


\section{BPV Committee on Nuclear Inservice Inspection (XI)}

Executive Committee (SC XI)

Special Working Group High Temperature Gas Cooled Reactors (SC XI)

Special Working Group Nuclear Plant Aging Management (SC XI)

Special Working Group on Editing and Review (SC XI)

Subgroup on Evaluation Standards (SGES)(SC XI)

Working Group on Flaw Evaluation (SGES) (SC XI)

Working Group on Operating Plant Criteria (SGES) (SC XI)

Working Group on Pipe Flaw Evaluation (SGES) (SC XI)

Subgroup on Nondestructive Examination (SGNDE) (SC XI)

Working Group on Personnel Qualification and Surface Visual and Eddy Current Examination (SGNDE) (SC XI)

Working Group on Procedure Qualification and Volumetric Examination (SGNDE) (SC XI)

Subgroup on Repair/Replacement Activities (SGRRA) (SC XI)

Working Group on Design and Programs (SGRRA) (SC XI)

Working Group on Welding and Special Repair Processes (SGRRA) (SC XI)

Subgroup on Water-Cooled Systems (SGWCS)(SC XI)

Working Group on Containment (SGWCS) (SC XI)

Working Group on Implementation of Risk-Based Examination (SGWCS) (SC XI)

Working Group on Inspection of Systems and Components (SGWCS) (SC XI)

Working Group on ISI Optimization (SGWCS)(SC XI)

Working Group on Pressure Testing (SGWCS)(SC XI)

Working Group on General Requirements (SC XI)

\section{Committee on BNCS Operations}

\section{Committee on Board (NCS) Strategic Initiatives}

Standards Committee on Cranes for Nuclear Facilities

Standards Committee on Nuclear Air and Gas Treatment

Standards Committee on Nuclear Quality Assurance

Standards Committee on Nuclear Risk Management (CNRM)

Addenda Project Team

CNRM Executive Committee

CNRM Fire PRA Working Group

CNRM Interpretations Committee

CNRM Joint Standard Configuration Control Project Team

CNRM Subcommittee for RISC Participation

CNRM Subcommittee on Applications

CNRM Subcommittee on Standards Planning

CNRM New Non-Light Water Reactors Plants Working Group (New Non-LWR WG)

CNRM Subcommittee on Technology

CNRM Advanced Light Water Reactors Working Group (ALWR WG)

Standards Committee on Qualification of Mechanical Equipment Used in Nuclear Facilities

Subcommittee on General Requirements (SC-GR)

Subgroup on Dynamic Qualification

Subcommittee on Qualification of Active Dynamic Restraints

Subgroup on QDR Development

Subcommittee on Qualification of Pump Assemblies

Subcommittee on Qualification of Valve Assemblies 


\section{Standards Committee on Operation and Maintenance of Nuclear Power Plants}

O\&M Executive Committee

O\&M Special Committee on Standards Planning

O\&M Subcommittee on OM Codes

O\&M Subgroup - ISTA/ISTC (SC-OMC)

O\&M Subgroup - ISTB (SC-OMC)

O\&M Subgroup - ISTD (SC-OMC)

O\&M Subgroup - ISTE (SC-OMC)

O\&M Subgroup on Air-Operated Valves (SC-OMC)

O\&M Subgroup on Check Valves (SC-OMC)

O\&M Subgroup on Diesel Generators (SC-S/G)

O\&M Subgroup on Functional Systems (SC-S/G)

O\&M Subgroup on Heat Exchangers (SC-S/G)

O\&M Subgroup on Loose Parts (SC-S/G)

O\&M Subgroup on Motor-Operated Valves (SC-OMC)

O\&M Subgroup on OM-29 (SC-S/G)

O\&M Subgroup on Piping Systems (SC-S/G)

O\&M Subgroup on Reactor Internals and Heat Exchangers (SC-S/G)

O\&M Subgroup on Relief Valves (SC-OMC)

O\&M Subgroup on Rotating Equipment (SC-S/G)

O\&M Subgroup on RTDs (SC-S/G)

O\&M Task Group on Pump Performance Based IST

O\&M Working Group on Pneumatically Operated Valves

Notes:

1. Lower reporting committees are not shown for those highest level committees that are not of significant interest to the development of rules for HTGRs.

2. BNCS organization structure as of August 25, 2010. 